Original Russian Text (C) 2019 O.V. Ryzhkov, G.A. Ryzhkova, published in Forest Science Issues Vol. 2, No. 3, pp. 1-50

DOI 10.31509/2658-607x-2020-3-1-1-34

\title{
USING METHODS OF GEOINFORMATION MAPPING FOR THE STUDY OF WOODY VEGETATION OF FOREST-STEPPE ECOSYSTEMS THE CENTRAL CHERNOZEM RESERVE
}

\author{
O.V. Ryzhkov*, G.A. Ryzhkova \\ V.V. Alekhin Central Chernozem State Nature Biosphere Reserve \\ Russia, 305528, Kursk oblast, Kursk district, Zapovedny settlement \\ *E-mail: ryzhkov_oleg@mail.ru \\ Received 15 June 2019
}

Methods of cartographic studies of the wood vegetation of the reserve, including those using modern GIS technologies and satellite positioning devices, are presented. Dynamics of the spatial structure and composition of oak forests over the past 50 years is analyzed. Results of the study of the main tree species of the reserve using GPS (GLONASS) survey and GIS are shown. Patterns and special features of the tree and shrub distribution in the open spaces (fallows, virgin steppes, and pastures) are presented.

Key words: forest-steppe, nature reserves, oak forests, mapping, GPS, GLONASS, satellite positioning devices, geographic information systems (GIS)

The forests of the Central Chernozem Reserve (CCR) are located in the southwestern part of the Central Russian Upland within the central strip of the forest-steppe zone (Kursk oblast). Ravine and watershed oak forests, mostly coppice ones, are predominant here.

It is a common fact that various types of digital cartographic materials presented in a certain system of coordinates or projection form the basis of geographic information systems (GIS). During the pre-GIS times (1950s to 1990 s), there were only hard copies of the maps of the reserve.

Mapping of the vegetation cover, including woody vegetation, has been used to study the natural complexes of CCR since the middle of the past century. A significant part of cartographic materials of that period was represented by geobotanical and forest management maps. The results of cartographic studies of that time are covered in a series of publications

(Kartometricheskie issledovanija..., 1975; Kashkarova, Rubajlo,
Utehin, 1973; Neshataev, 1970, 1983, 1996; Neshataev, Novikova, Uhacheva, 1982; Petrova, 1990; Ryzhkov, Sobakinskih, 2006; Utehin, 1967, etc.). Cartographic work mainly involved continuous planimetric eye survey, creating a stationing grid on the ground and writing down the results on paper. Plant associations or their complexes and types, i.e. polygons in the modern sense of GIS, were used as mapping units. Large territorial units of the CCR (sites and ecosites) usually were the objects of research.

The geographical location of the Central Chernozem Reserve, which lies in the central forest-steppe zone, determines the direct contact between forest and steppe vegetation, so many researchers have been paying great attention to the relationship between them. A separate cycle of mapping on the reserve territory included studying the distribution of tree and shrub species in strictly protected areas (both virgin and former fallow lands). The most studied fallow in this respect is Dalneye Pole fallow of Kazatsky site of CCR, 
a part of which (29.6 ha) was mapped three times: in 1970, 1980, and 1999-2000. The survey of 1970 and 1980, resulted in preparation of location maps of the bases of tree trunks and contours of shrub thickets (Krasnitskij, 1973; Krasnitskij, Soshnin, 1984), and the mapping of 1999-2000 resulted in a detailed map of projective covers of trees and shrubs (both single and thickets-forming). Dynamics of the distribution of woody vegetation on Dalneye Pole fallow was analyzed in a series of papers (Ryzhkov, Ryzhkova, 2000a,b,c; Ryzhkova, Ryzhkov, 2001). It is exactly the mapping of tree and shrub distribution across the steppe that underlies the testing of modern survey methods, which is the subject of this article.

Forest management works were carried out 5 times (in 1953, 1968, 1979, 1990 and 2000) within the territory of the reserve. Afforestation plans were made in hard copies, and it was only in 2000 that both hard copies and electronic versions were created (maps were digitized at the federal state institution Voronezhlesproject, initially in WinGIS software with subsequent conversion to MapInfo in Cartesian coordinates).

Multi-temporal series of geobotanical and forest management maps objectively reflect the general trends in vegetation dynamics. However, taking a plant association or a forest type as a mapping unit suggests significant errors in the accuracy of rendering their contours, which is also due to subjective factors. In our opinion, the most detailed and complete reflection of the dynamics of woody vegetation is provided by regular cartographic works performed at stationary research sites, or SRSs (permanent test plots (PTPs), profiles, transects, registration sites, individual restricted access facilities, etc.). In this case, real individual trees and shrubs or their biogroups (thickets) are taken as mapping units. SRSs mapping of vegetation, in contrast to more generalized geobotanical mapping, is of paramount importance, since in this case, due to the high accuracy of the grid $(5 \times 5 \mathrm{~m}$ or $10 \times 10 \mathrm{~m}$ ) and terrain association, a detailed and objective survey of the vegetation cover is provided, and, accordingly, high-quality maps of various thematic areas are obtained. Obviously, no linking natural objects and geographical coordinates, which are used in modern GIS, were not even in question during the pre-GIS period.

The cartographic materials compiled from surveys on stationary sites are the most accurate and objective in terms of reflecting the statics and dynamics of vegetation cover, forming the basis for a comprehensive study, analysis and modelling of the development of natural ecosystems. Stationary cartographic works are even more important when repeated, which makes it possible to track local and global dynamic trends of the vegetation (Ryzhkov, 2006b). The method of stationary studies of woody vegetation in nature reserves has been published before (Ryzhkov, 1996b).

Stationary methods of studying the vegetation cover of the reserve have been being practiced on its territory since the end of the World War II. N. A. Prozorovsky laid the first two permanent test plots for the study of forest vegetation of the CCR in the forest ecosites Dubroshina and Solovyatnik on Streletsky site in 1945 (Letopis' prirody..., 1949). G. M. Zozulin mapped these PTPs repeatedly in 1950 and analyzed the dynamics of changes in their vegetation over a five-year period (Zozulin, Kusmarceva, 1951). The results of one of the first cartographic studies are also provided in the scientific report of the reserve for 1949-1950 (Letopis' prirody..., 1951), which contains diagrams of distribution of tree and shrub vegetation in logs compiled by G. M. Zozulin. Special symbols designating the bases of tree trunks and clusters of shrubs were approximately applied on the diagrams according to relief features. These images are a prototype of modern mapping materials based on GPS (GLONASS) survey of woody vegetation. In the following years, cartographic research on the SRSs of the reserve was conducted by G. M. Zozulin (1952), S. S. Levickij (1958, 1961), F. I. Hakimzyanova (1968), A. M. Krasnitskij (1963), and others. The full review of these works was given by (Ryzhkov, 2006b).

A number of forest PTPs was laid in 1963 by A. M. Krasnitskij and in 1968 and 1979 during subsequent forest management measures, in the oak forests of the CCR, where forest-taxation studies are carried out from time to time, in particular complete 
enumerations and mapping of stands, undergrowth, understorey and grass cover. These PTPs now form the basis of the GIS forest unit of the CCR.

Modern methods of the vegetation mapping have been implemented in the reserve. These methods make use of new satellite positioning devices, unmanned aerial vehicles (UAVs), and desktop and mobile geo-information systems.

The objective of this paper is to give a review of cartographic research results in the CCR and demonstrate the advantages of using modern GIS software and hardware to study forest-steppe ecosystems.

The tasks of this paper are: to show the dynamics of forest vegetation based on the materials of periodic mapping at the PTPs, to assess the state of stands of the main species, and to present the findings of studying tree and shrub distribution in the steppe.

Several methodological approaches are distinguished, depending on the types of source data intended for GIS. Next, the methods and results of mapping woody vegetation at SRSs will be discussed.

\section{MATERIALS AND METHODS \\ 1. Transferring data to GIS by scanning hard copies of cartographic bases with or without subsequent vectorization of its objects}

The eye survey of tree and shrub vegetation on forest PTPs was preceded by creation of a stationing grid of $5 \times 5 \mathrm{~m}$ on the ground. Layout plans of trunk bases and projections of tree crowns by species and tiers (also showing standing dead trees and windthrow) were drawn at a scale of 1:100 on grid paper in the field for each test plot. It is the horizontal structure of forest communities on 14 SRSs, namely, the projective cover of stands, undergrowth and understorey based on mapping data from 1991-1993 and 2002 (Ryzhkov, Ryzhkova, 2006a) which was studied in greatest detail. This method was fully polished when mapping complex watershed oak forests and waterlogged birch forests of the Zorinsky site of the CCR (Zolotuhin, Ryzhkov, Filatova, 2001; Ryzhkov, Ryzhkova, 2001).

In 2002-2006, those paper plans were scanned and their fragments were stitched into single bitmaps. Next, it would technically make sense to register the resulting rasters directly in the GIS and vectorization directly in association with terrain. However, no desktop GIS version was available in the reserve during mapping and creating the electronic map archive. Therefore, digitization was made in AutoCAD. The objects were vectorized manually ("on the screen") in Cartesian coordinates. As a result, layers that reflect the location of trunk bases and projections of tree crowns of each tree species were obtained, which allowed us to estimate their quantitative proportions by automatically calculating the area (previously, the areas of crown projections had to be measured on a paper base with a planimeter, which led to overestimation of the values by about 4\% (Ryzhkov, 2006c)). Guidelines were developed for rasters digitizing in AutoCAD and subsequent usage of the resulting vector objects in GIS (Ryzhkov, 2000; Ryzhkov, Vlasov, 2000; Ryzhkov, 2001a; Ryzhkov, 2006a).

As the licensed version of the MapInfo Professional GIS appeared in the reserve, it became necessary to link the AutoCAD-vector layers of crown projections of the stands to the bases of tree trunks, as well as the projective coverings of undergrowth and understorey of forest PTPs. The standard MapInfo tool allows registration of vector layers only by three reference points, which is clearly not enough for accurate transformation. Therefore, we used the loose MiTransformer module, which, based on affine or projective transformations, allows registering vector objects of several tables at once using an unlimited number of reference points which provides high quality of terrain association.

To automatically create a vector layer of basal areas of tree trunks at forest PTPs, the function of creation circle with the given centre and given diameter in the MapCAD module was used, and the values of the latter were taken from the numeric field of the table (database) (Ryzhkov, 2013). Trunk centres were marked on top of the bitmap by manual application of a symbol inside each circle.

Transformation of vector objects in GIS from a LAYOUT projection (Cartesian coordinates) to one of GIS map projections 
may be followed by emersion of artefacts, i.e. foreign details or noise of the resulting objects (e.g., distortion of border smoothness) that are absent in the original objects. Basal areas are easily adjusted by constructing centroids to generate circles with given diameters. Correct transformation of the borders of crown projection polygons requires preliminary generalization (thinning) of their nodes using appropriate GIS software (MapInfo or ArcGIS).

The following approach, which is currently used, is better in terms of methods and time. The raster of each forest PTP is registered in the MapInfo Professional GIS (current license Advanced v.16.0.4) using four boundary points, the coordinates of which are determined by static survey in the leafless period using modern GNSS equipment (Trimble GeoExplorer 6000 GeoXH CE receiver) with $0.2-0.3 \mathrm{~m}$ accuracy (achieved with long-term recording of coordinates in RTK mode with a fixed device). Further, in the GIS environment, the objects were vectorized manually on the screen with terrain association in the universal transverse Mercator projection (zone 37, Northern hemisphere (WGS 84) [EPSG:32637]) and subsequent analytical calculations are carried out (Ryzhkov, Ryzhkova, 2019b). The mapping materials of the stands of the watershed oak forest of the "Poyma Psla" site of the CCR were processed this way (Ryzhkov, Ryzhkova, 2019a).

The described method based on digitization of paper diagrams allows using map materials obtained in a conditional (usually Cartesian) coordinate system in GIS. The next two methods are based on data from field surveys of objects with satellite positioning devices of different classes, which makes possible their export to GIS based on the obtained geographical coordinates.

\section{Total survey using personal navigation devices and GIS}

GPS (and/or GLONASS) survey, which is performed by satellite positioning devices, is one of the ways of quick collection of data for GIS. These devices can record geographical coordinates of waypoints and tracks and store them in non-volatile memory. It was the use of GPS receivers that, starting in 2000, initiated the creation of geospatial databases in the
CCR. The reserve staff is currently using over 10 portable Garmin GPS navigators (GPSMAP 76CSx, GPSMAP 78S, OREGON 550, GPSMAP 64ST, etc.) as well as smartphones and tablets, including protected ones, with the location detection function. The above-named mobile equipment makes it possible to navigate through bitmaps.

The resulting point and line objects were exported to GIS using specialized software. The finishing processing (boundary smoothing, converting polylines to polygons, etc.) was made with geoinformation systems. The main disadvantages of this method are its inability to save the necessary attributes with graphics, and low accuracy of recording coordinates (3-5 $\mathrm{m}$ and more). Certain guidelines have been prepared for collecting GPS data (Ryzhkov, Ryzhkova, 2006b, Ryzhkov, 2014b) and their processing in the MapInfo GIS environment, in particular creating smoothed polygons (Ryzhkov et al., 2013; Ryzhkov, 2014a), sharing GPS (GLONASS) devices and GIS during mapping of natural objects in real time (Ryzhkov, 2010, 2011), and a review of methods for geoinformation mapping of natural objects and their application in protected areas has been published (Ryzhkov, 2008, 2009b).

\section{Total survey using high-precision} GNSS equipment, UAVs, mobile and desktop GIS

Starting from 2016, detailed cartographic studies have been carried out at the CCR including application of modern hardware and software, i.e. high-precision GNSS equipment, UAVs, mobile and desktop GIS. This equipment was tested when mapping the distribution of trees and shrubs on the Second unmowed section of the Streletskaya steppe which is the largest and most representative part of the Streletsky site (with an area of 101.6 ha). This object has been completely protected since 1935. No total ground mapping was arranged here previously.

The work involved the Trimble GeoExplorer 6000 GeoXH CE two-frequency satellite receiver and two UAVs - DJI Inspire1 Pro of the cartography laboratory of the Institute of Geography of the RAS and DJI Inspire-1 of the Central Chernozem Reserve. Mapping was carried out in real time (RTK) 
mode with continuous reception of corrections via 3G-modem from the Regional centre for navigation services for Kursk oblast (planimetric accuracy of recording the objects' coordinates under open sky was $2-3 \mathrm{~cm}$ ). The high-resolution pictures, obtained from drones, were used to create orthophotomaps of the terrain and refine controversial contours in hardly accessible areas of steppe shrub thickets.

Data was processed, analysed, and visualized in MapInfo Professional v.15.2.4 64bit GIS environment, raster was converted in Global Mapper v.13.0, and data management was made in Trimble GPS PathFinder Office v.5.81. Mobile application: TerraSync Centimeter Edition v.5.41 based on Windows Mobile v.6.5.

High accuracy of location detection by the Trimble GeoExplorer 6000 GeoXH CE allowed using a virtual stationing grid for mapping instead of a real one, the creation of which required considerable effort during conventional mapping of vegetation cover in previous periods. Such a two-layer virtual stationing grid with a square size of $100 \times 100$ $\mathrm{m}$ (1 ha) was formed in the GIS environment MapInfo Professional v.15.2.4 64bit with the Create Grid tool (hectare squares were further divided into smaller squares of $10 \times 10 \mathrm{~m}(1$ are) in order to minimize skips of young individuals when mapping). The main and additional stationing grids with unique numbering of squares were uploaded into the device in SHP format for subsequent stakingout.

With the mobile GIS TerraSync of the Trimble GeoExplorer 6000 GeoXH CE receiver, it is possible to use background raster maps (satellite images, forest management diagrams, etc.) in GeoTIFF format as support mats. Raster and vector images were uploaded to the receiver via the GPS PathFinder Office v.5.81 Data Transfer module. TRIMBLE has also developed a stand-alone Data Transfer program for the same operation.

A unique feature of the GPS PathFinder Office desktop software is the ability to develop a mobile GIS structure as a field data collection form with a specific list of fields, which was used during the woody vegetation survey.
Two types of data were saved during mapping: point (trunk bases) and polygonal (crown projections) ones. At the same time attribute information based on these data was collected.

Field work included mapping of woody vegetation with a complete enumeration of trees and shrubs (all specimens starting from the immature age state were taken into account, and juvenile plants found were also recorded). Trimble GeoExplorer $6000 \mathrm{GeoXH}$ determined geographical coordinates and altitude of the trunk bases of single trees and shrubs above sea level, in order to consistently form an array of waypoints suitable for building point-based thematic maps in GIS. Isolated contours (thickets) of vegetation were mapped by traversing their perimeter with the above device. At the same time, polygon nodes were entered into the receiver's memory every second. The device was configured to record only high-quality objects, the planimetric coordinate error of which did not exceed the set value (in most cases, it is usually $2-3 \mathrm{~cm}$ when the sky is open and $50-100 \mathrm{~cm}$ under tree crowns and in dense thickets of shrubs).

Simultaneously with the mapping, detailed attribute information was collected for each object. For a complete enumeration in the field, the following information was entered in a special form: site, ecosite, author(s), date, time, polygon or point number, species, origin, trunk perimeter or diameter at breast height $(\mathrm{cm})$, trunk height $(\mathrm{m})$, age, condition, diseases, life form, fructification, notes for entering additional information and photos (only selected objects were photographed).

Parallel to ground mapping of woody vegetation, aerial photography of the section was carried out with DJI Inspire-1 drones. The resulting pictures were combined into single images that were used to create orthophotomaps of the unmowed area. Some photographs, including images of tree and shrub crowns in hardly accessible areas (impassable thorny thickets), were recorded separately in GIS and used as an underlay for manual digitizing of the crown contours on the screen.

The point layer of distribution of single trees and shrubs and the polygonal layer of projective covers of tree and shrub vegetation 
of the Second unmowed section of the "Streletskaya steppe", obtained in the mobile GIS TerraSync Centimeter Edition v.5.41, together with all attributes were exported via MIF exchange files to the MapInfo GIS. They were used to create 1:5000 and 1:400 thematic maps (on 134 pages). A detailed method of GIS mapping of woody vegetation using modern hardware and software was published by (Ryzhkov et al., 2017).

Let us mention, that the direct application of high-precision geodetic devices for mapping woody vegetation under the forest canopy lacks efficiency since there are significant obstacles for satellite signals. Even when receiving differential corrections in RTK mode, the accuracy of determining coordinates in this case usually does not exceed $1.0 \mathrm{~m}$, which is clearly not enough for correct coordinate recording. In addition, stable mobile or radio connection is required. Therefore, conventional mapping involving the creation of a stationing grid on the ground or geodetic devices of another class, e.g. total stations which use the line-and-angle resection is preferred in highly closed stands. The staff of the reserve has certain experience in operating such equipment.

\section{RESULTS AND DISCUSSION}

We used the methods described above to study both individual components of foreststeppe ecosystems and general trends in their dynamics. It makes sense to show the patterns of weather changes in the studied area prior to making results review. The CCR has its own weather station "Streletskaya Steppe", which has been taking continuous observations 8 times per day since 1947. Analysis of the dynamics of the main weather parameters has shown that over the recent 20 years, annual air temperatures has been exceeding the average long-term values (Fig. 1), whereas the amount of precipitation has been equal to or lower than the average values (Fig. 2). In general, over the entire observation period, the average annual air temperature increased by almost $1{ }^{\circ} \mathrm{C}$ (from $5.0^{\circ}$ (1956) to $5.9^{\circ}(2019)$ ). Thus, according to long-term observations, the weather in the reserve area has become hotter and drier. However, the last decade is characterized by significant weather extremes including abnormally high amounts of precipitation in certain months (Table, Fig. 3).

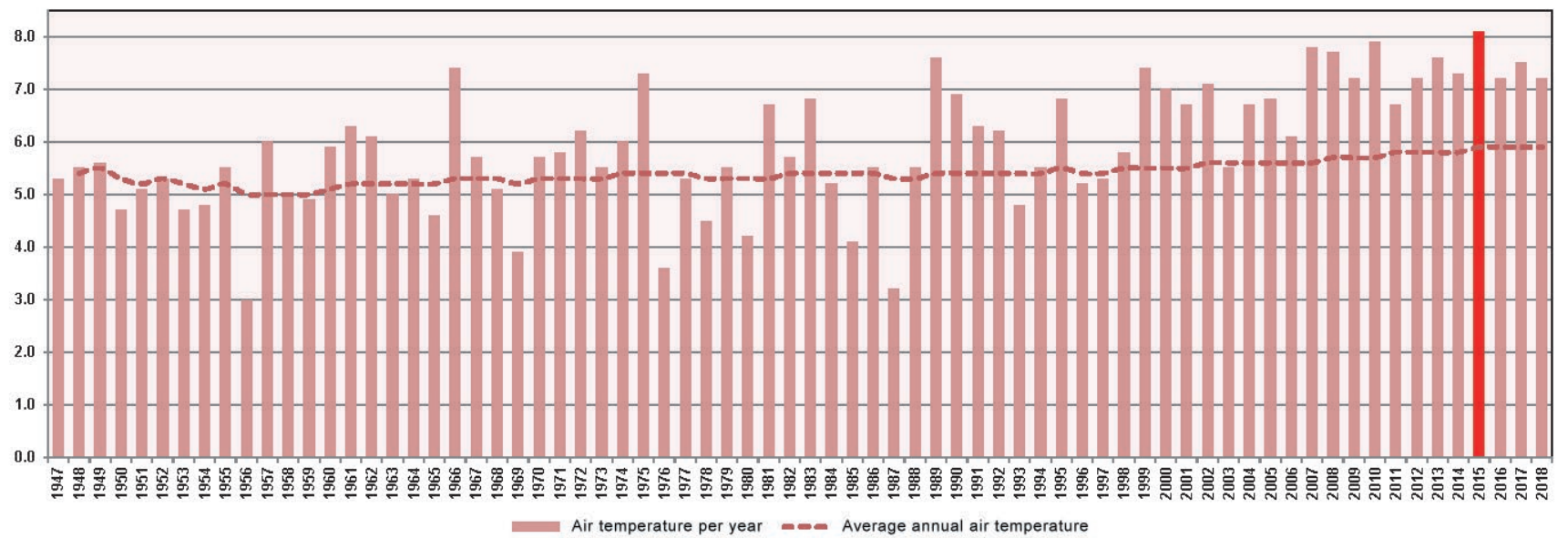

Figure 1. Long-term dynamics of average annual air temperature 


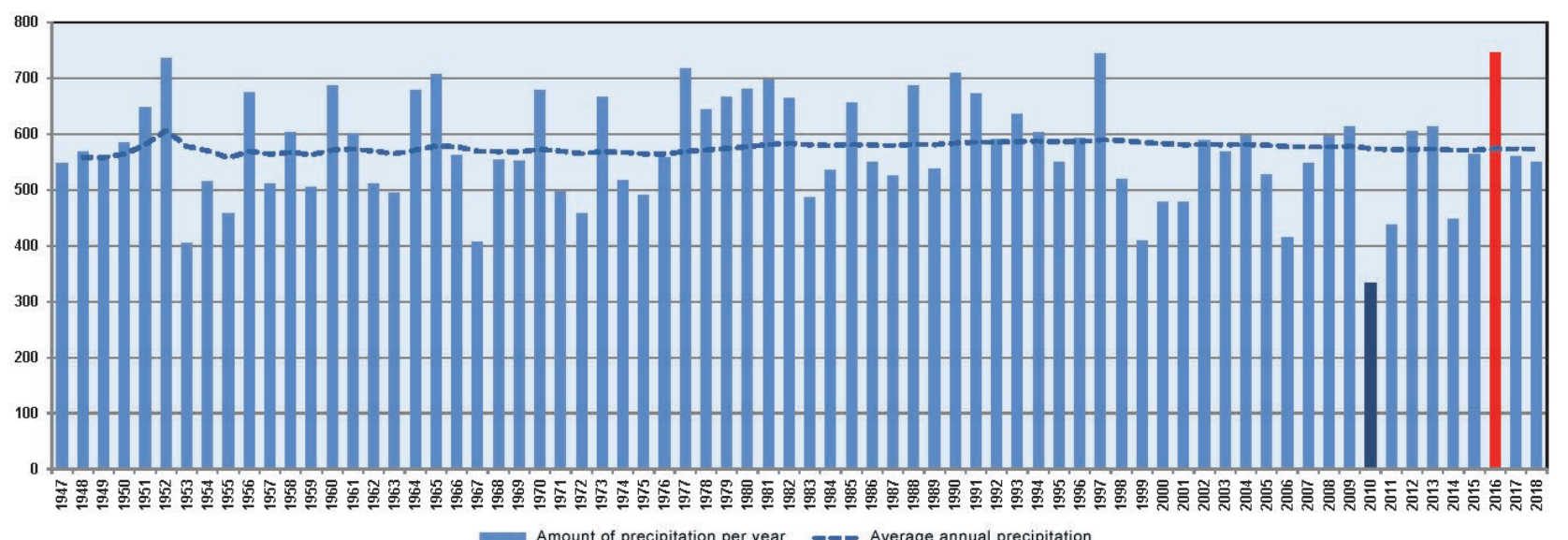

Figure 2. Long-term dynamics of annual precipitation

Table. Extreme values of air temperature and precipitation in the last decade (2010-2019) in the CCR area during the observation period since 1947.

\begin{tabular}{|c|}
\hline 2010 \\
\hline $\begin{array}{l}\text { Abnormal heat (absolute maximum air temperature }+39.2^{\circ} \mathrm{C} \text { ) and drought (absolute minimum of } \\
\text { precipitation } 333.8 \mathrm{~mm} \text { ) }\end{array}$ \\
\hline 2015 \\
\hline The average annual air temperature exceeded $+8^{\circ} \mathrm{C}\left(+8.1^{\circ} \mathrm{C}\right)$ for the first time \\
\hline 2016 \\
\hline The wettest year (absolute maximum amount of precipitation $746.4 \mathrm{~mm}$ ) \\
\hline 2017 \\
\hline The rainiest December (absolute maximum amount of precipitation $126.2 \mathrm{~mm}$ ) \\
\hline 2018 \\
\hline The rainiest July (absolute maximum amount of precipitation $221.5 \mathrm{~mm}$ ) \\
\hline The driest August (absolute minimum amount of precipitation $4.4 \mathrm{~mm}$ ) \\
\hline $\begin{array}{l}\text { The highest air temperature was recorded in September; previously this had been the case as far } \\
\text { back as in } 1963 \text {. }\end{array}$ \\
\hline
\end{tabular}

General weather characteristics and features in the area of the reserve were published by (Nepochatyh, Ryzhkov, 2016). Long-term series of observations of the climate and biota of the reserve allowed identifying the main climate-influenced trends in changes in biotic components of biogeocenoses over the past 100 years (up to 1999) (Ryzhkov et al., 2001; Ryzhkov et al., 2018). As mentioned above, the early 21 st century is characterized by significant climate changes, the impact of which on the CCR flora and fauna was analyzed in $2000-2013$, and the results of the research were published in 2017 (Ryzhkov et al., 2017a,b). These weather trends and anomalies have certainly affected the structure and dynamics of the forest vegetation of the CCR, which is reflected by the results of the research. We present the main findings including those obtained with the help of analytical GIS tools and based, in particular, on the construction of digital terrain models (DTMs) and generation of DTMs-based derived vector coverage to study the spatial distribution of trees of individual species by altitude, slopes and direction of slopes. 


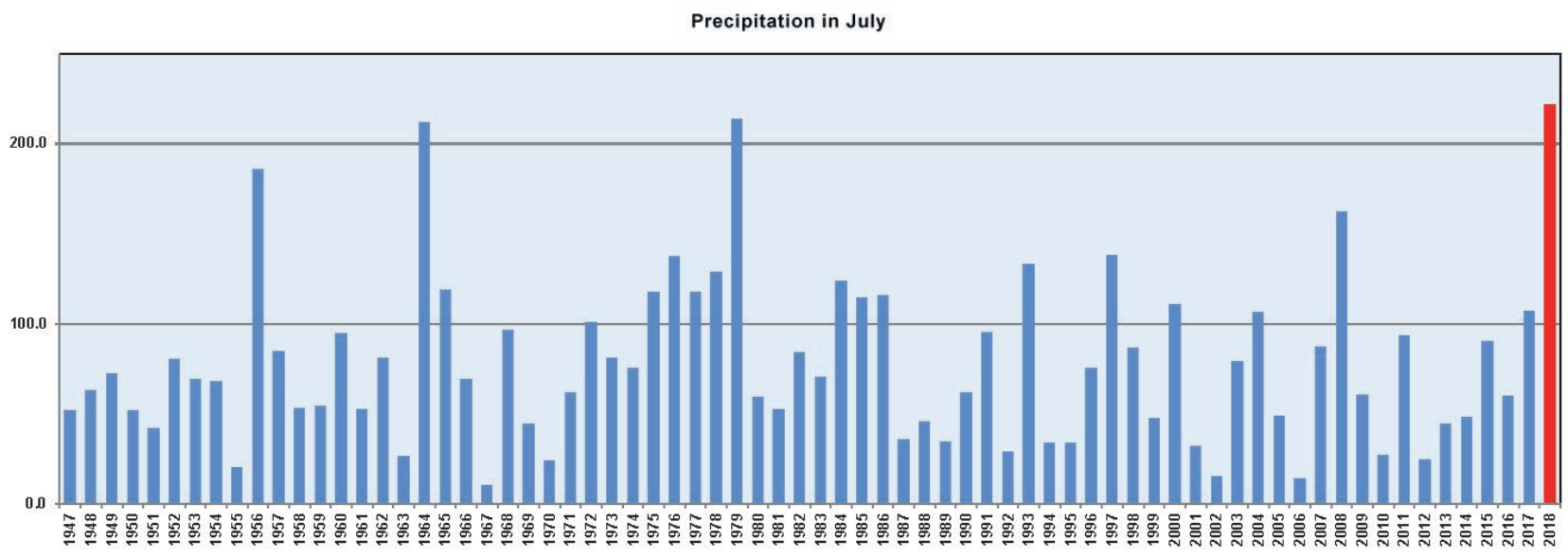

Precipitation in August

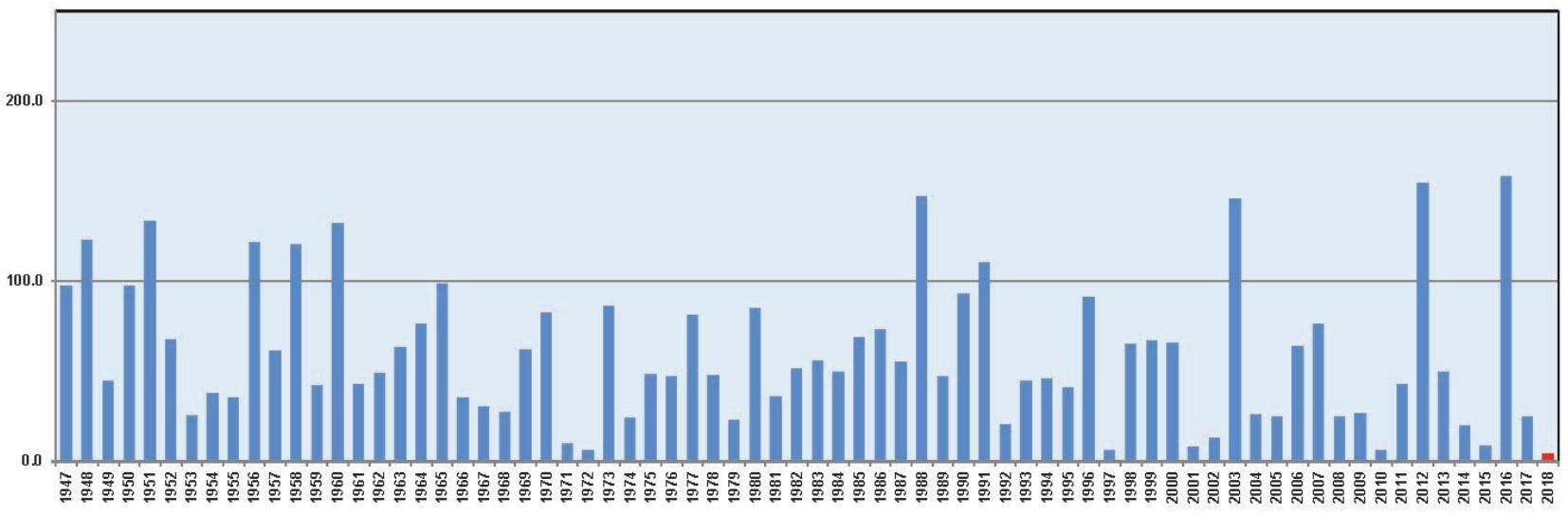

Precipitation in December

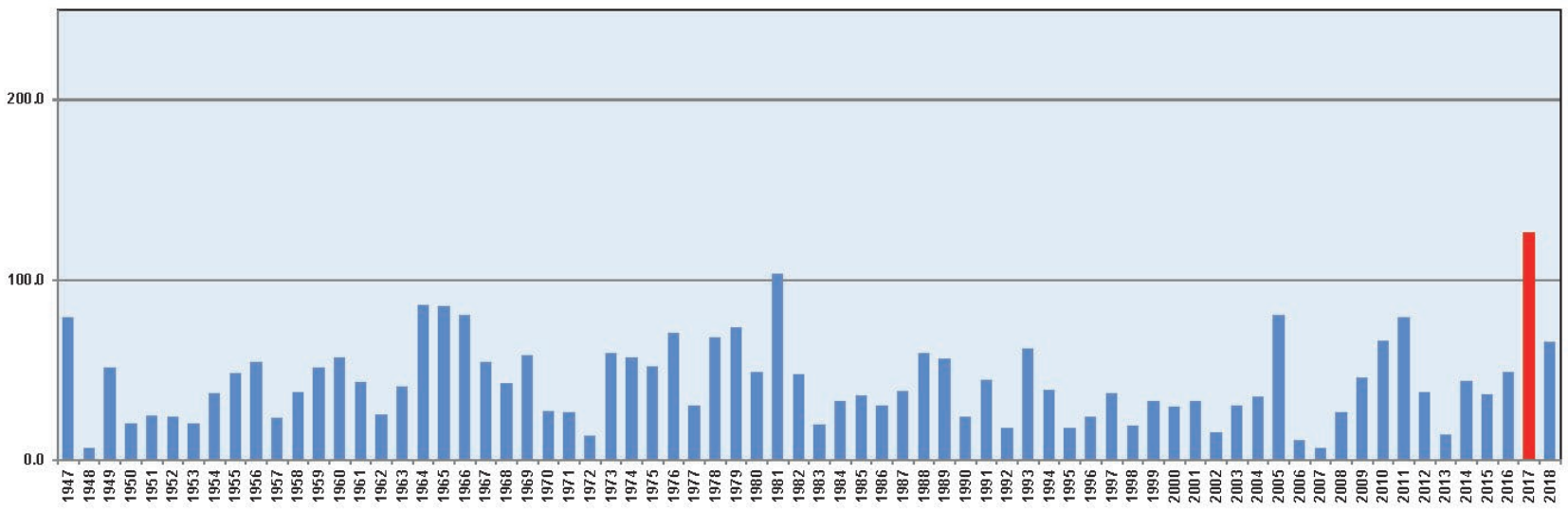

Figure 3. Abnormal climate indexes of recent years (according to the "Streletskaya Steppe" weather station)

\section{Dynamics of the spatial structure of oak trees (projective cover of stands, undergrowth and understorey) on forest PTPs based on mapping data of different years}

The results of research in this area were being reported in the public literature in 19952019 (Ryzhkova, Ryzhkov, 1995; Ryzhkov, 1996; Ryzhkov, Ryzhkova, 1999; Ryzhkov,
Ryzhkova, 2001, Ryzhkov, Ryzhkova, 2006a).

1. In the 1960s, the oak stands of the CCR, having the common oak (Quercus robur L.) as the edificator species, were far more differentiated by tiers. Their overall projective cover was maximal and relatively uniform. The associated species were insignificant in the horizontal structure of communities (Fig. 4). 


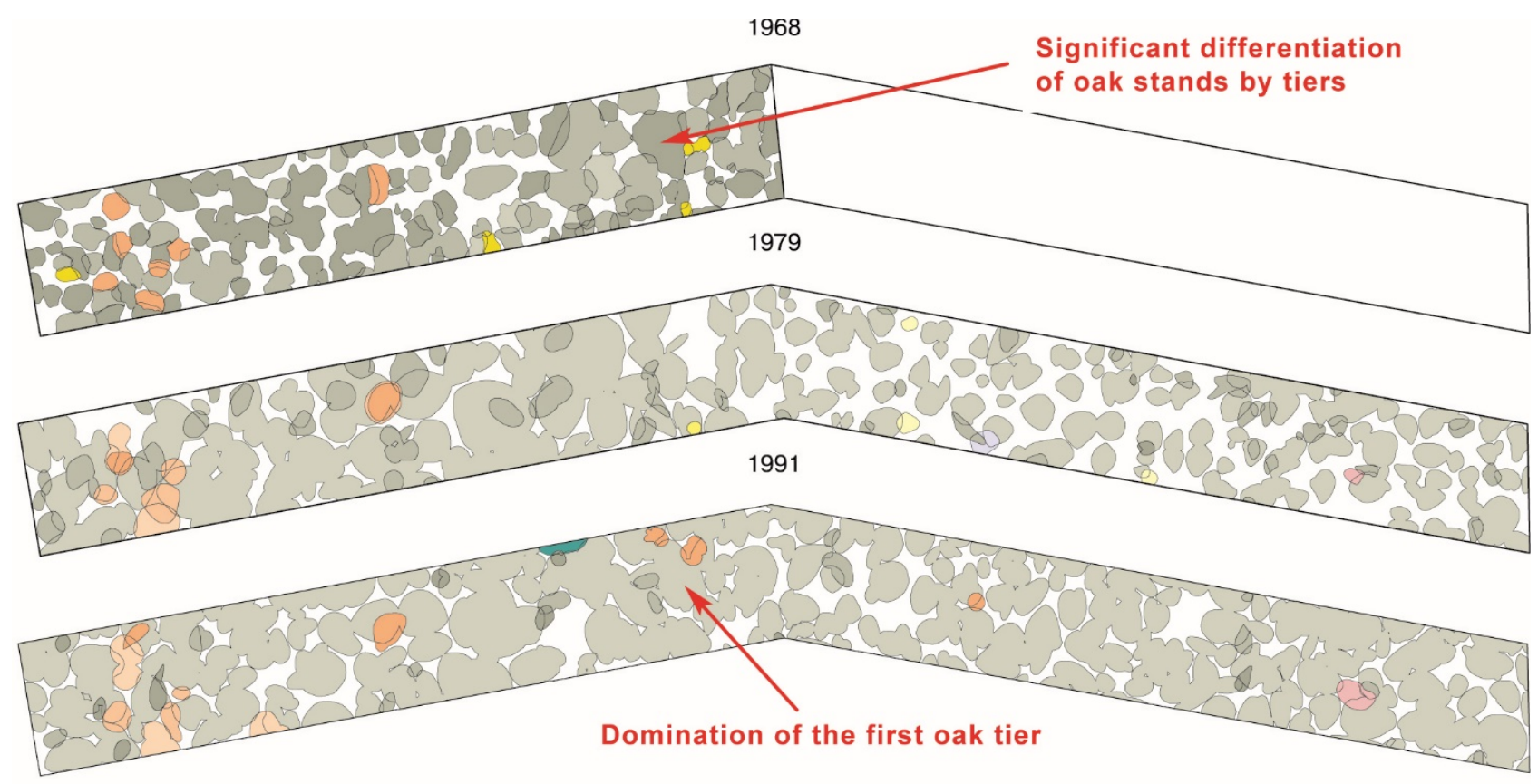

Figure 4. Dynamics of the structure and species composition of the forest stand from 1968 to 1991. (Streletsky site of the CCR, Babka ecosite, forest PTP No. 12)

Note. Figure legend:

\begin{tabular}{|c|c|}
\hline Tier & SPECIES \\
\hline 1 & \multirow{3}{*}{ Betula pendula } \\
\hline 2 & \\
\hline 3 & \\
\hline 1 & \multirow{3}{*}{ Ulmus sp. } \\
\hline 2 & \\
\hline 3 & \\
\hline 1 & \multirow{3}{*}{ Pyrus pyraster } \\
\hline 2 & \\
\hline 3 & \\
\hline 1 & \multirow{3}{*}{ Quercus robur } \\
\hline 2 & \\
\hline 3 & \\
\hline 1 & \multirow{3}{*}{ Salix caprea } \\
\hline 2 & \\
\hline 3 & \\
\hline 1 & \multirow{3}{*}{ Acer platanoides } \\
\hline 2 & \\
\hline 3 & \\
\hline 1 & \multirow{3}{*}{ Acer campestre } \\
\hline 2 & \\
\hline 3 & \\
\hline 1 & \multirow{3}{*}{ Acer tataricum } \\
\hline 2 & \\
\hline 3 & \\
\hline 1 & \multirow{3}{*}{ Acer negundo } \\
\hline 2 & \\
\hline 3 & \\
\hline 1 & \multirow{3}{*}{ Tilia cordata } \\
\hline 2 & \\
\hline 3 & \\
\hline 1 & \multirow{3}{*}{ Populus tremula } \\
\hline 2 & \\
\hline 3 & \\
\hline 1 & \multirow{3}{*}{ Malus praecox } \\
\hline 2 & \\
\hline 3 & \\
\hline 1 & \multirow{3}{*}{ Fraxinus excelsior } \\
\hline 2 & \\
\hline 3 & \\
\hline
\end{tabular}


2. As a result of the massive drying of oak forests in the forest-steppe in the 1970s, there was a significant thinning of stands in the CCR, mainly due to the death of undersized and stunted oak trees. Vertical stratification of communities became simpler, which was manifested in the dominance of the first tree tier (Fig. 4). Large gaps were formed in the forest canopy. The total projective cover of stands decreased (Fig. 5).

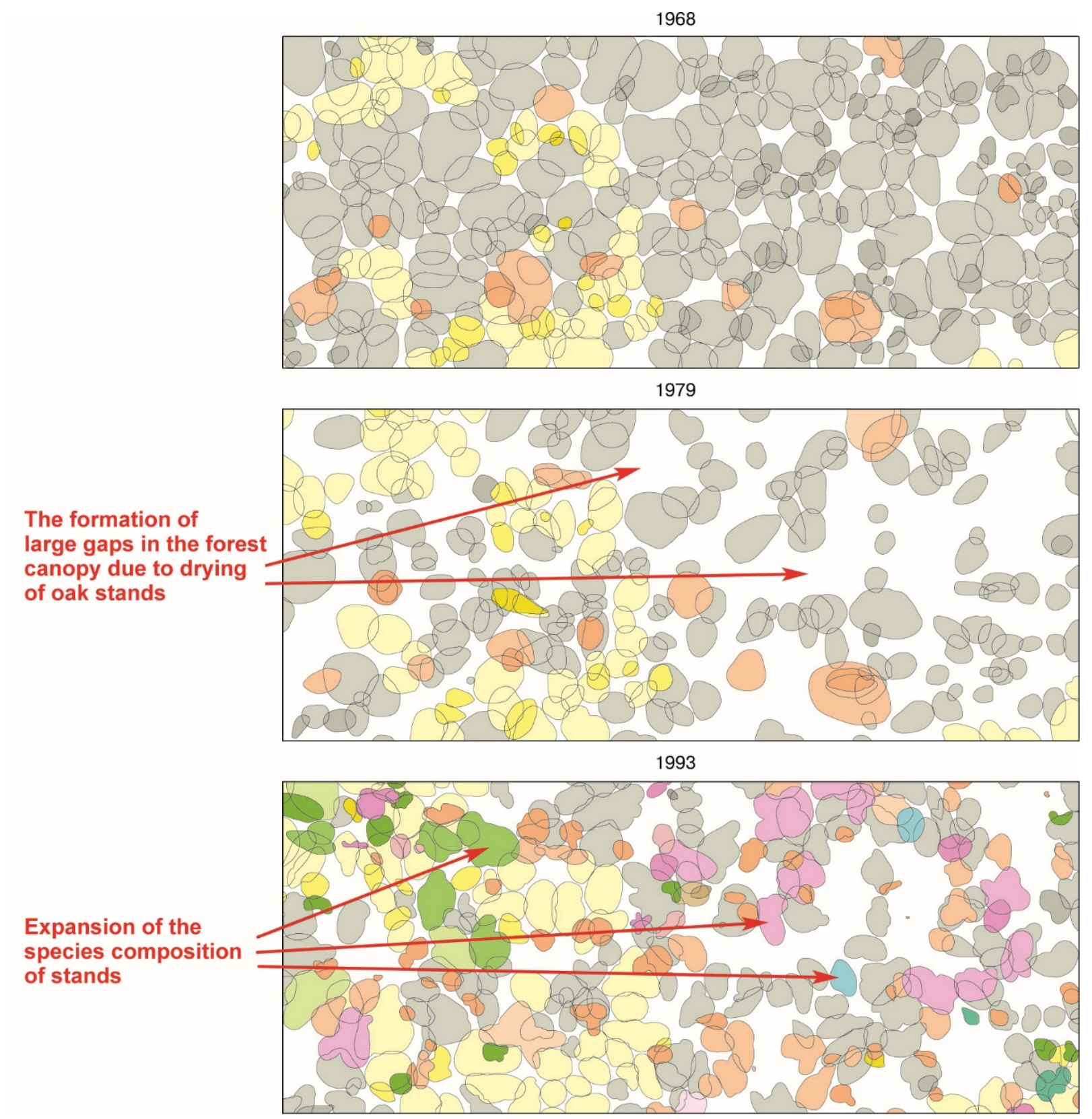

Figure 5. Dynamics of the structure and species composition of the forest stand from 1968 to 1993.

(Kazatsky siteof the CCR, Kazatsky forest ecosite, forest PTP No. 6)

Note. For figure legends, see the note to Fig. 4.

3. Due to changes in the light regime, the resulting gaps became quickly colonized by broad-leaved oak associates (especially Norway maple) and wild fruit species, which had significantly expanded the species composition of stands by 1990s (Fig. 5, 6)
(Ryzhkov, 1997). A chronological gap is observed in the populations of the common oak: exclusively mature generative trees continued to dominate, whereas, with rare exception, there were no individuals of pregenerative fractions. 


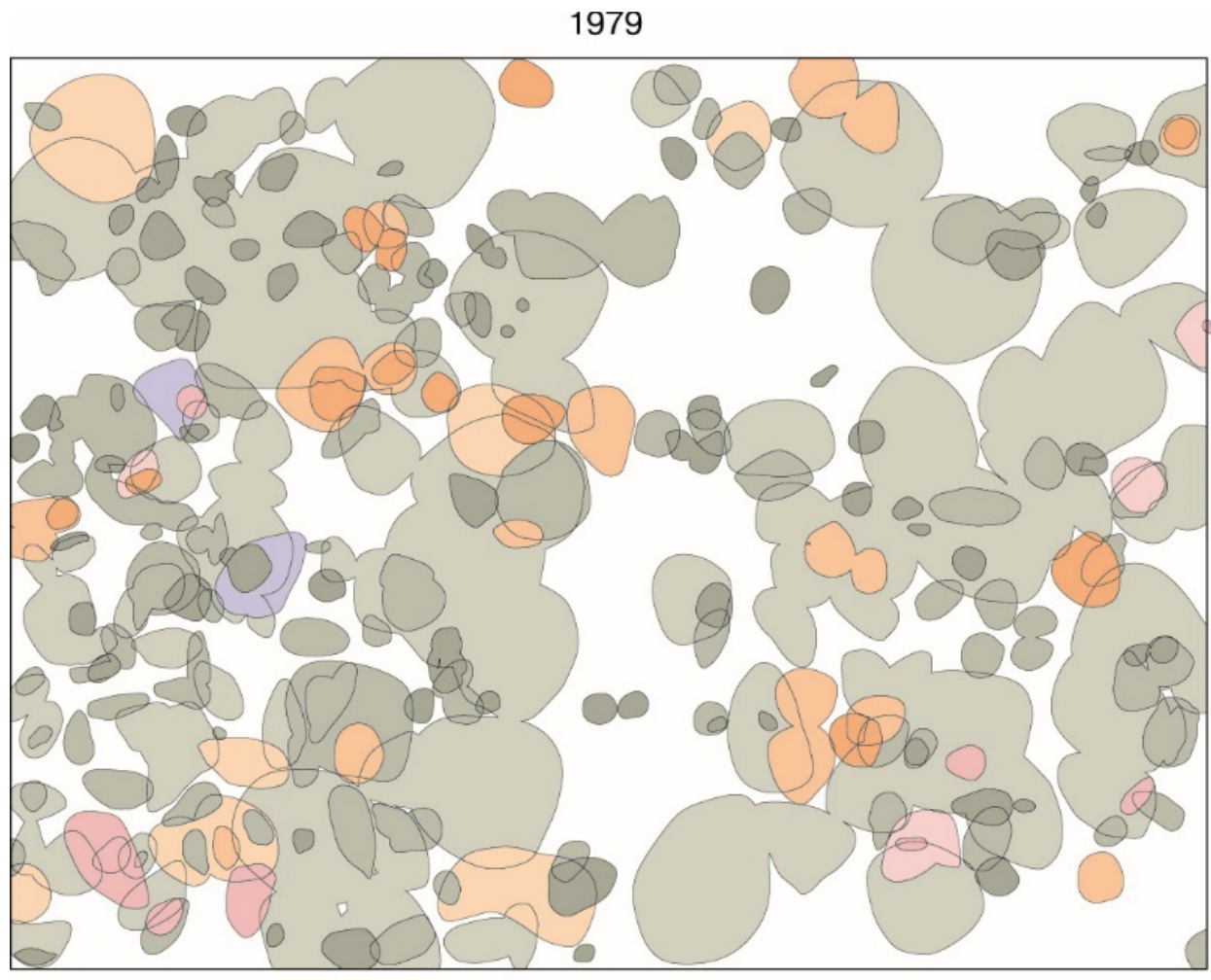

1993

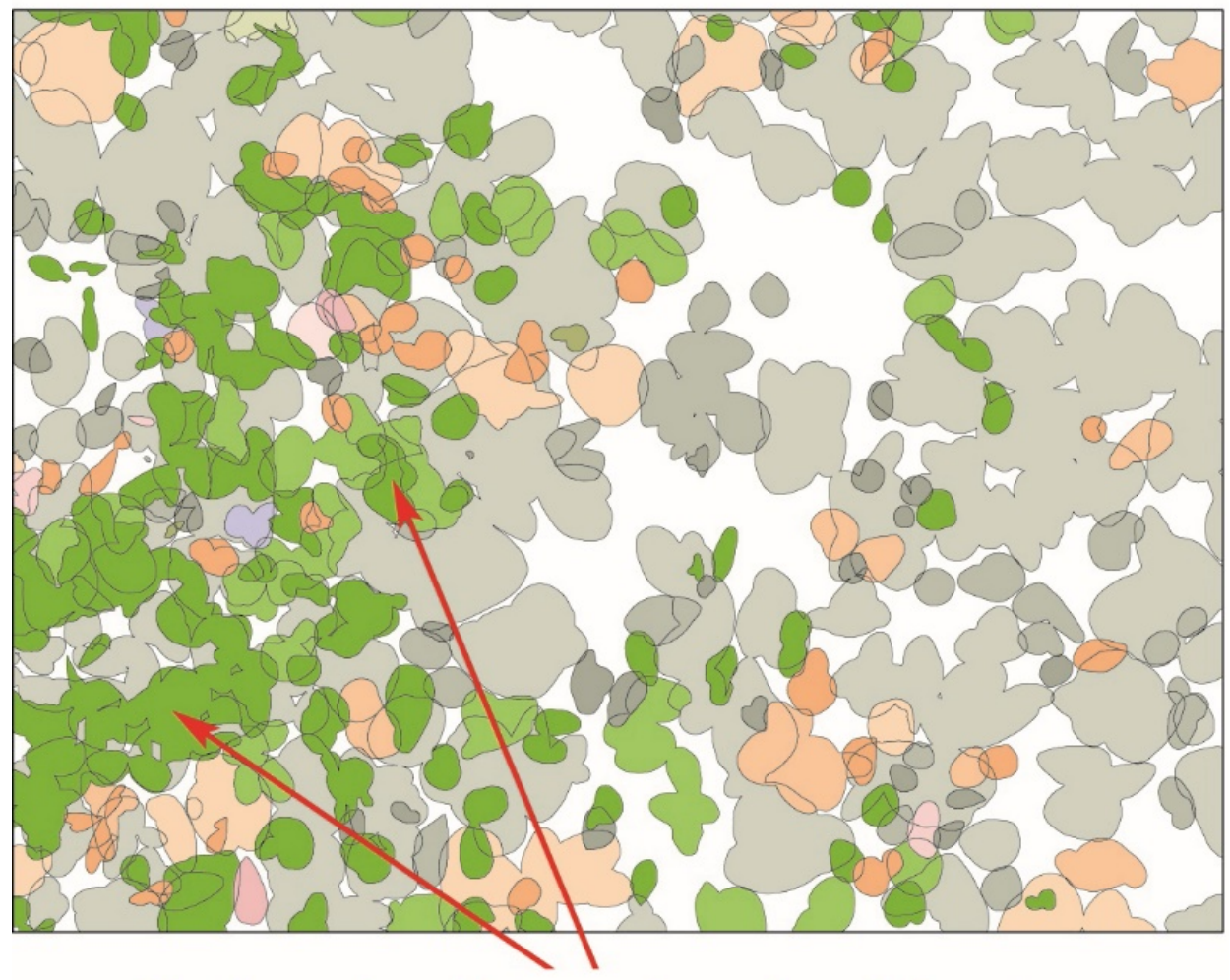

The formation of types of maple-oak forest

(the intensity of invasion in the stand of Acer platanoides - about 50 specimens per 1 ha per year)

Figure 6. Dynamics of the structure and species composition of the forest stand from 1968 to 1993.

(Streletsky site of the CCR, Dedov-Vesely ecosite, forest PTP No. 19)

Note. For figure legends, see the note to Fig. 4. 
4. Oak forests have powerful undergrowth which was formed by bird cherry (Prunus padus L.) (Ryzhkova, Ryzhkov, 2003; Ryzhkova, Ryzhkov, 2004) and (or) common hazel (Corylus avellana (L.) H. Karst.) which created additional obstacles to the successful regeneration of the oak. At the same time, bird cherry inhabits mainly simple-structured coppice oak forests with common oak dominating the tree tier: cherry creates dense undergrowth, in which it accounts for more than $90 \%$ of the projective cover (Fig. 7). Moreover, within the reserve this species can participate in the third and even second tiers of the stand. The formation of cherry-oak forests is observed in some forest ecosites which is a unique forest type for the forest-steppe. Hazel, on the contrary, is usually confined to complex multi-species broad-leaved forests. As populations of this species mature, small isolated contours merge into large continuous loci with very high projective cover (Fig. 8). Over time, hazel actively settled in the forests of Kazatsky and Streletsky sites of the CCR including in watershed areas where it was previously either absent or exterminated (Fig. 9). According to the findings of three-time large-scale geobotanical mapping made by Yu.N. Neshataev $(1968,1979,1993)$, the area of distribution of Corylus avellana increased from 55.4 to 97.0 ha (Ryzhkov, 2001b) in Kazatsky forest. From 2008 to 2014, we were performing complete mapping of the common hazel population of Streletsky site of the CCR using Garmin personal navigators. The resulting waypoints of location of the bushes' bases were processed with GIS analytical tools. For example, derived maps created on the basis of Streletsky site DTM were used for automatic sorting of hazel detection locations by altitude, slope ranges, and slope directions using MapInfo Professional geographic operators and SQL queries (Ryzhkov, Ryzhkova, 2010a; Ryzhkova, Ryzhkov, 2011; Ryzhkov, Ryzhkova, 2014b). A similar GPS survey was made on the same area for smallleaved linden (Ryzhkov, Ryzhkova, 2010b).

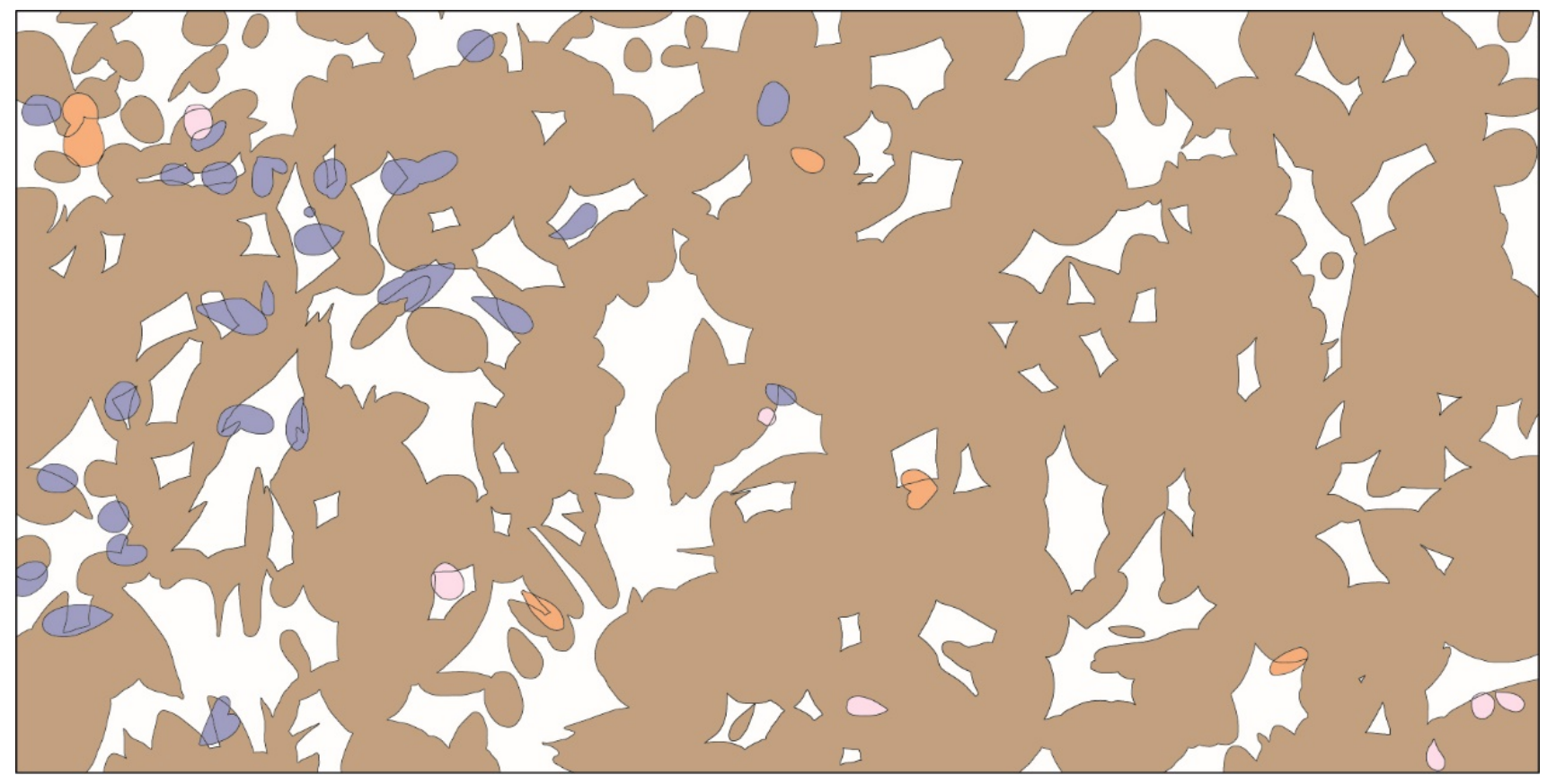

Figure 7. Projective cover of bird cherry

(Streletsky site of the CCR, Petrin Les ecosite, forest PTP No. 9, 1992) 
1977

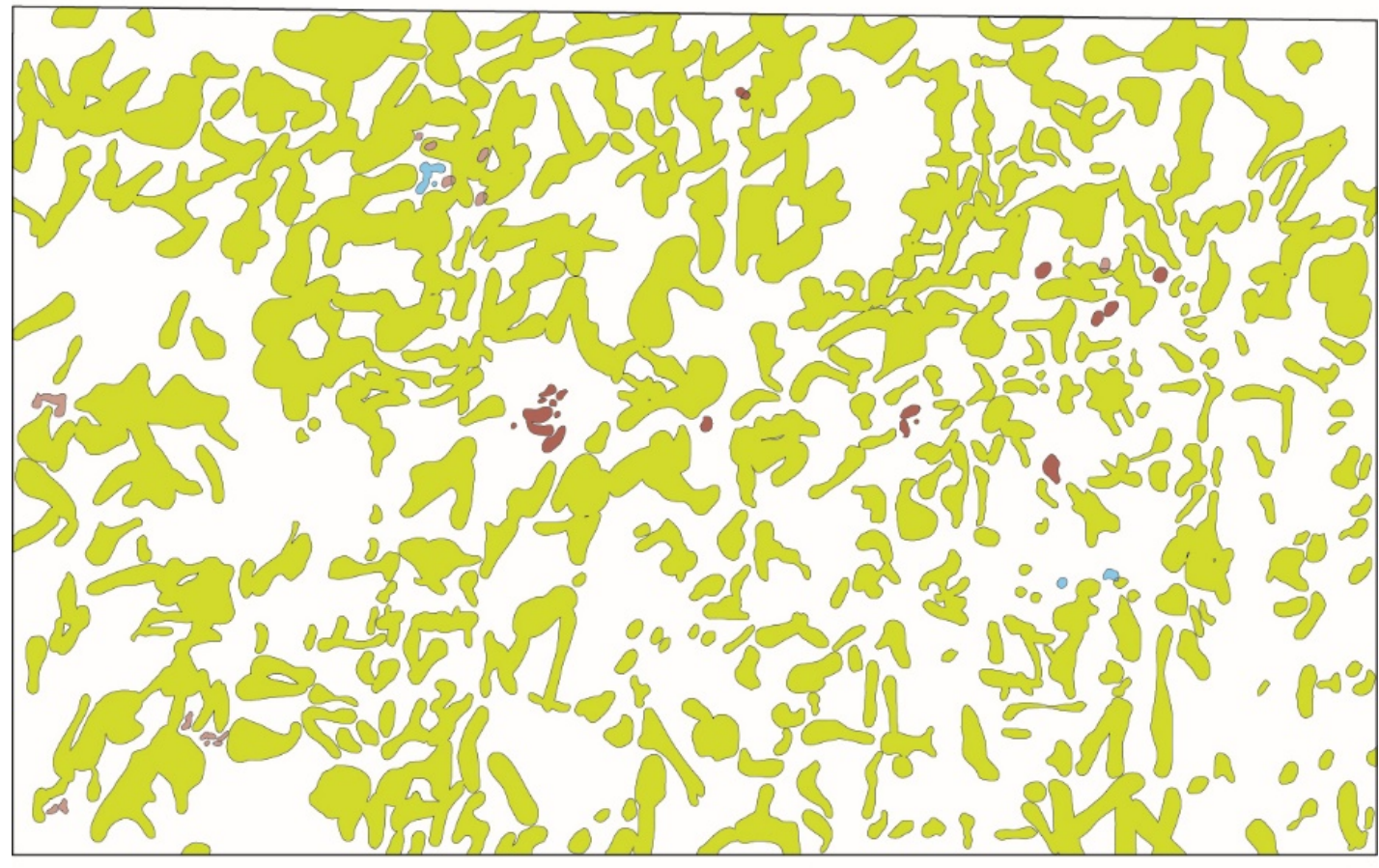

2002

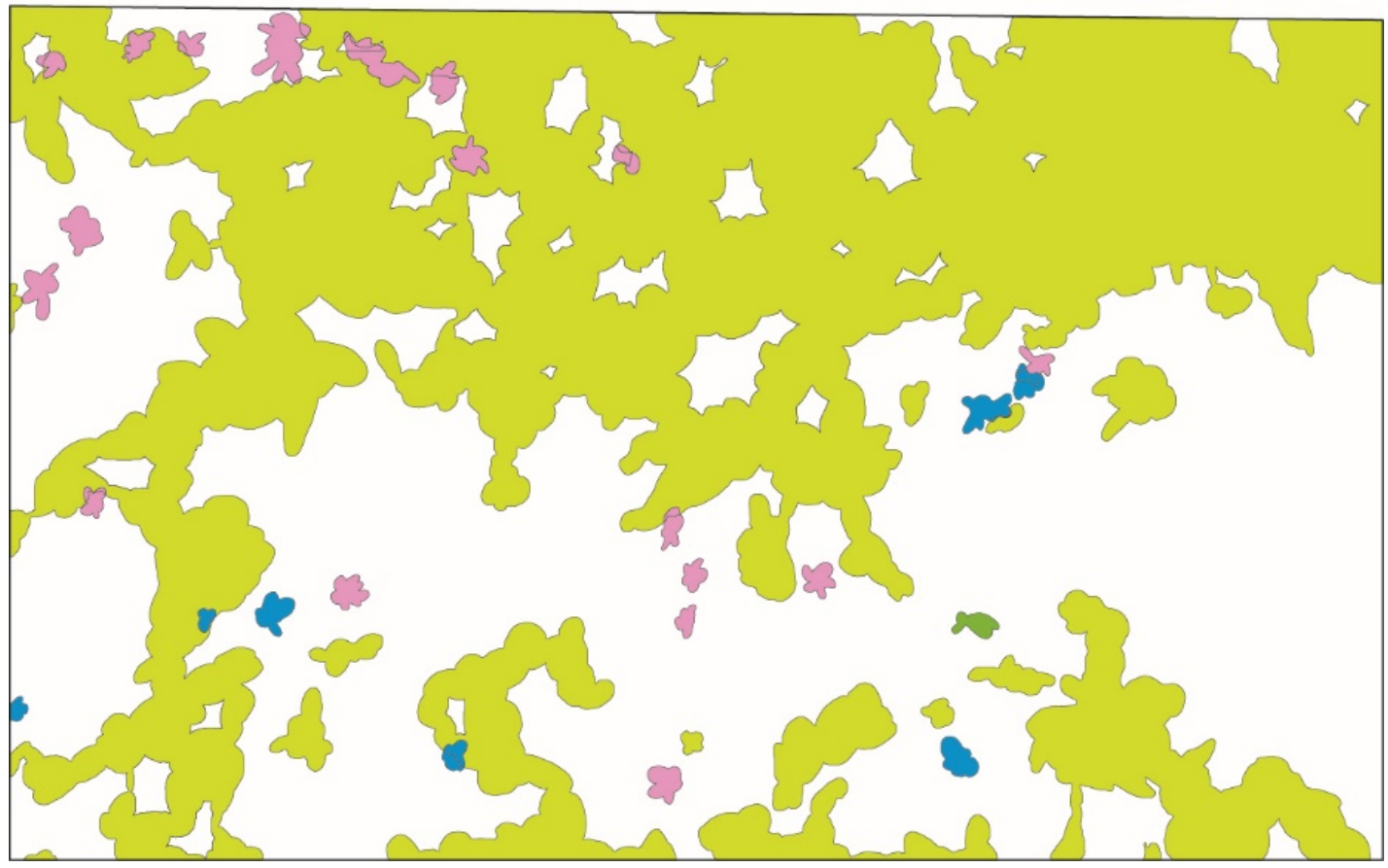

Figure 8. Dynamics of the horizontal structure of the common hazel population (Kazatsky site of the CCR, Kazatsky forest ecosite, forest PTP No. 4) 


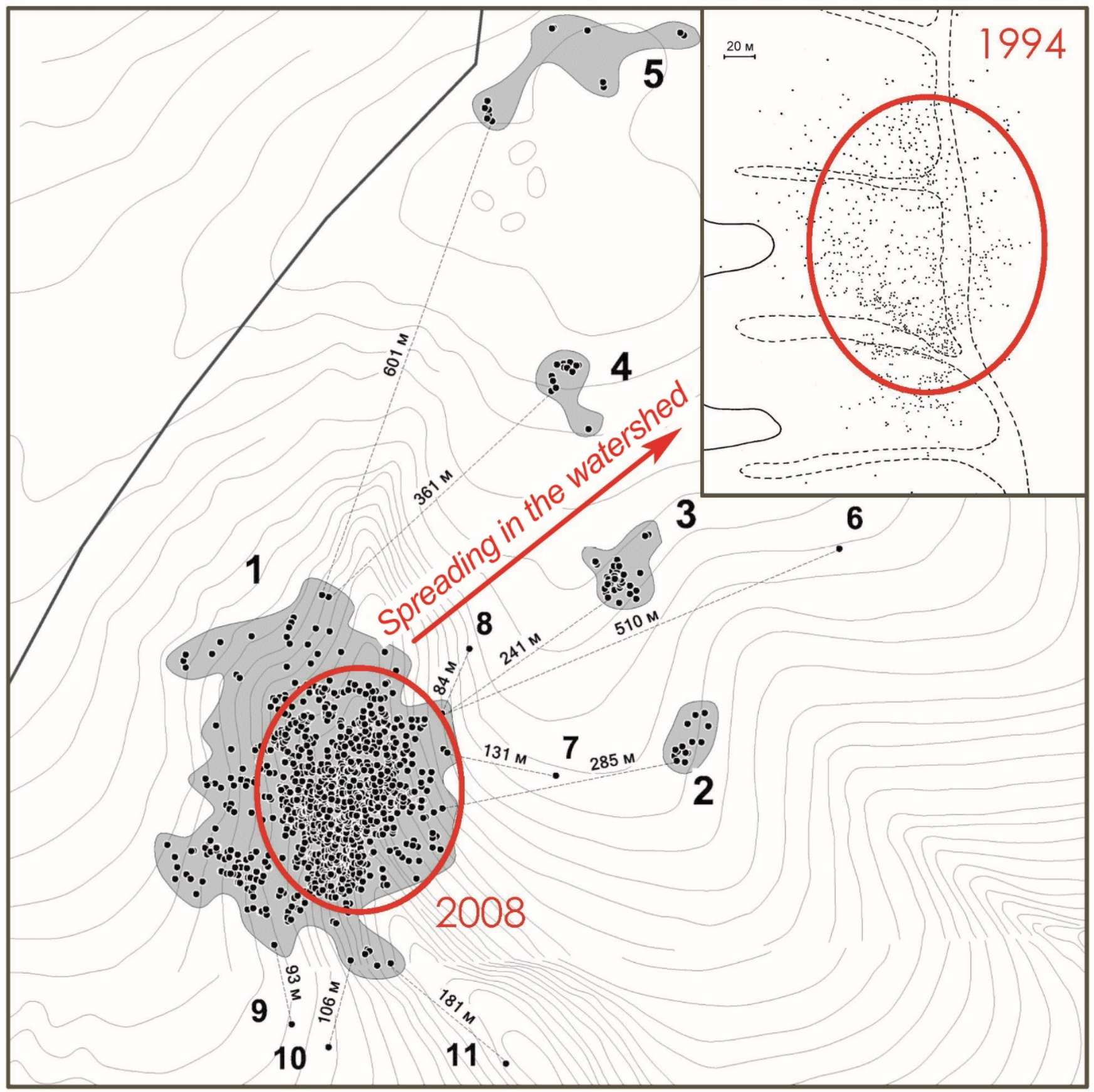

Figure 9. Resettlement of the common hazel from Temnaya hollow to the watershed in Dubroshina ecosite of the Streletsky site of the CCR (based on mapping materials from 1994 and 2008)

5. Currently, natural thinning of parent stands of oak of vegetative origin and strengthening of phytocenotic positions of other broad-leaved species continues. The last local foci of reserve oak forests drying were recorded in 1999-2000 and were associated with late spring frosts, the consequences of which were aggravated by summer droughts (Fig. 10). 


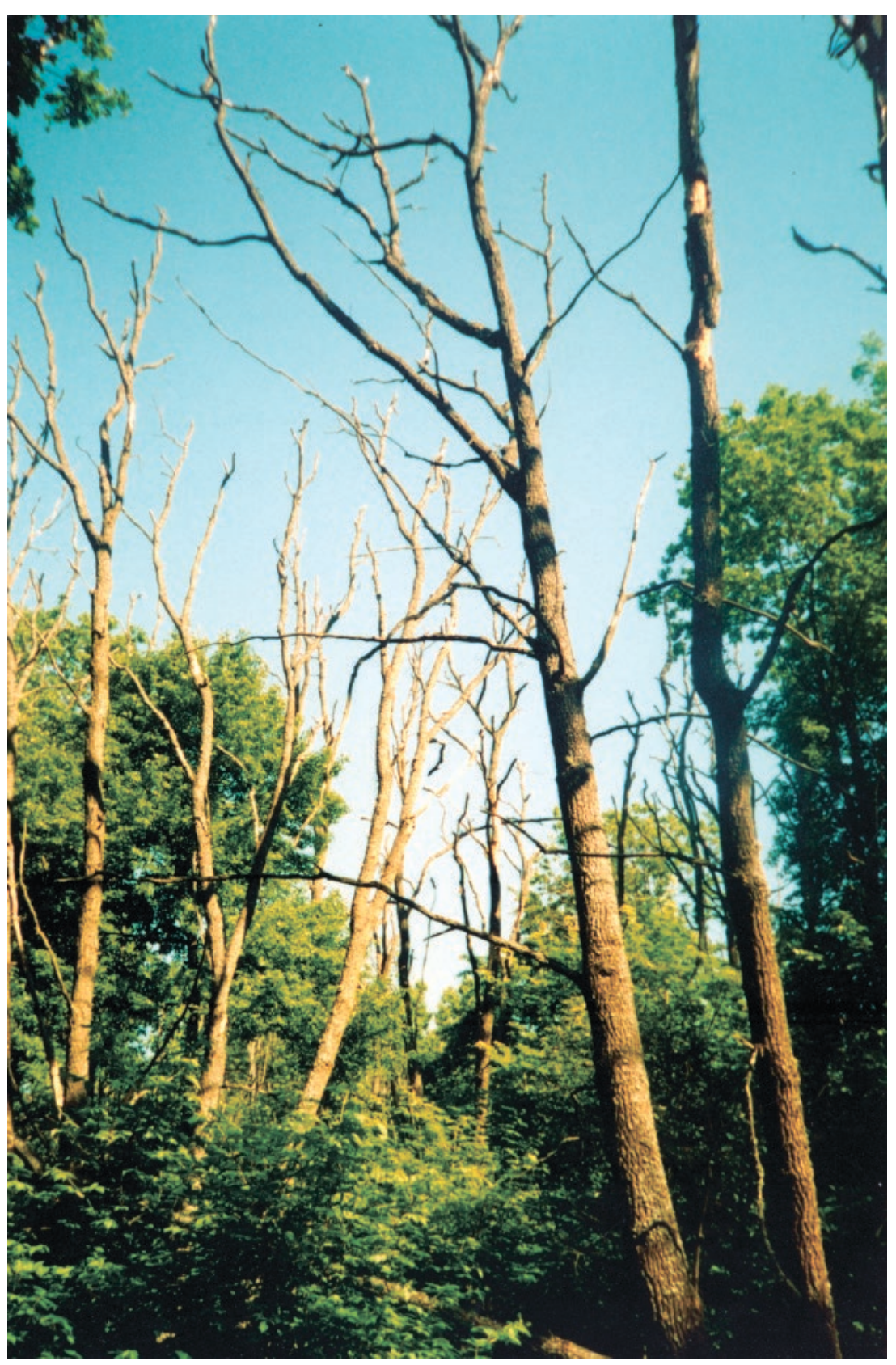

Figure 10. Local drying of an oak in Temnaya hollow (Dubroshina ecosite, Streletsky site of the CCR)

In 1999-2000, about 20 oak trees per 1 ha were lost in the reserve's oak forests. The rate of thinning of oak stands was low during the subsequent period from 2001 to 2018. On average, 1 to 8 trees per 1 ha died every year (Fig. 11). 


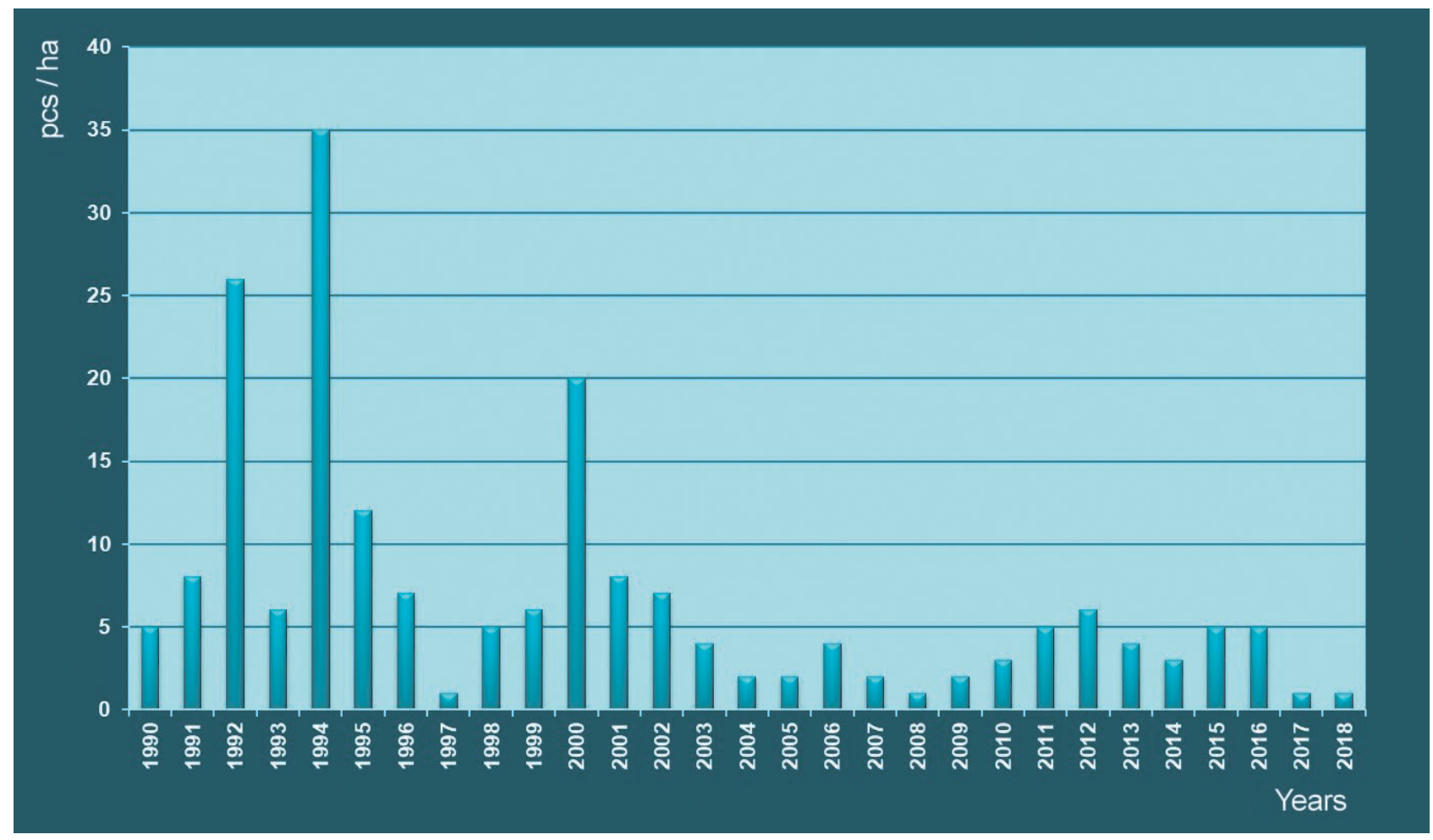

Figure 11. Long-term dynamics of current common oak mortality in the CCR (according to the data on 13 forest PTP)

The dynamics of the number of dry trees changed dramatically against the background of ongoing active fall of old standing dead oak trees and rare appearance of fresh standing dead wood. From 1970 to 2000 the process was undulating, with slight changes in the number of standing dead wood ranging from 150 to 250 trees/ha, but starting from 2001, there was a pronounced trend of a constant annual decrease in this figure (Ryzhkov O. et al., 2013). By 2018, the amount of standing dead oak trees has decreased to 73 trees/ha the all-time low, which is explained, on the one hand, by the absence of current foci of oak dying-off, and on the other hand, by active turning of standing dead wood into windthrow. Windthrow (partly windsnap) of dead trees contributes to the progressive accumulation of dead wood, which in 2018 amounted to 542 trees/ha, whereas the stock was over $84 \mathrm{~m}^{3} /$ ha.

Thus, the following features are typical for the process of oak mortality in the forests of the CCR in the last decade:

- stable annual decrease in the number and stock of standing dead trees and the same stable increase in these indicators for windthrow;
- low rates of thinning of oak stands.

The data on the trees of common oak that have changed their life state are regularly updated in the GIS on the PTP maps.

During World War II, the majority of the reserve's oak stands were cut down, with the exception of a small number of so-called "standards", which had been $40-45$ years old by that time. In 2008-2010, we carried out GIS mapping of such old-aged oak trees that were found in Streletsky site (Fig. 12).

6. Shade broad-leaved forests are starting to form within the modern boundaries of the forest-covered area of the CCR. This is evidenced by the dynamics of the species composition of the young generation in oak forests surveyed during repeated mapping on individual forest PTPs, these forests represented mainly by broad-leaved oak associates (Ryzhkov, Ryzhkova, 2004). Rejuvenation of forest-forming species populations is observed only in those habitats where illumination is not a limiting factor of the environment (clearings, ecotones with steppe, etc.). 


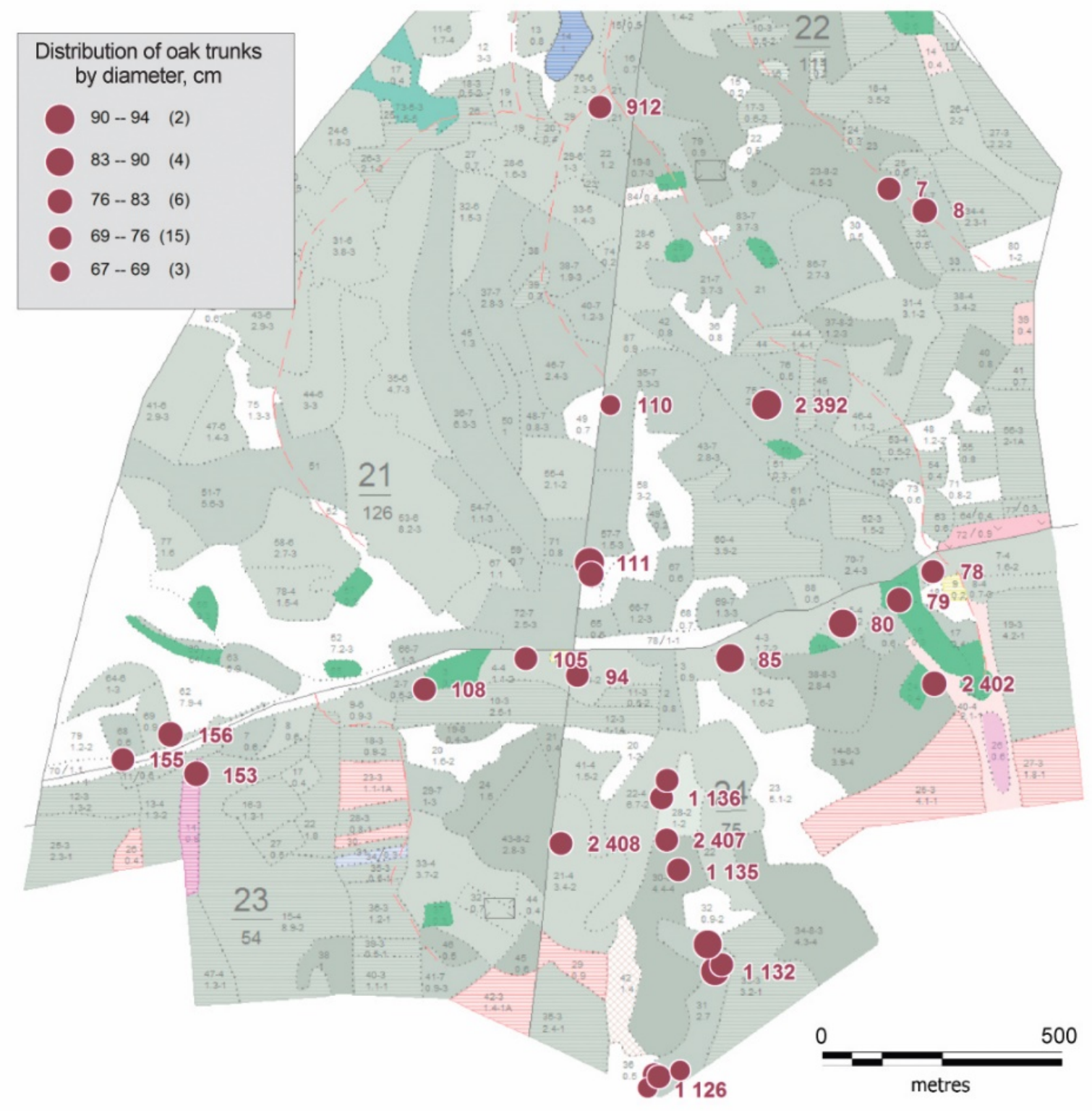

Figure 12. Scheme of distribution of old-aged common oak trees in Dubroshina and Solovyatnik ecosites of Streletsky site of the CCR (2010)

We have carried out cartographic studies of common oak populations in the areas of contact between oak forests and open spaces (former fallows and virgin unmowed steppes). An important result of this work is the assessment of the current status and population structure of the major forestforming species of the forest-steppe zone. The largest and most representative unmowed section of Streletskaya steppe, which was surveyed in detail in 2016, turned out to be a suitable area for self-reproduction of seed oak forests in the reserve. Coppice oak stands in the CCR gradually die off and do not produce viable offspring under their canopy. The success of oak regeneration in the ecotone zone of the unmowed section is objectively confirmed by mapping materials. Its population enjoys a full-fledged structure with a clear predominance of young trees (Fig. 13). We are currently witnessing the initial stage of formation of highly productive seed oak stands that will replace the coppice stands (Ryzhkov O. et al., 2017b,c). This conclusion is valid only for the areas with light mode of open places in natural areas of contact between forest and steppe. 


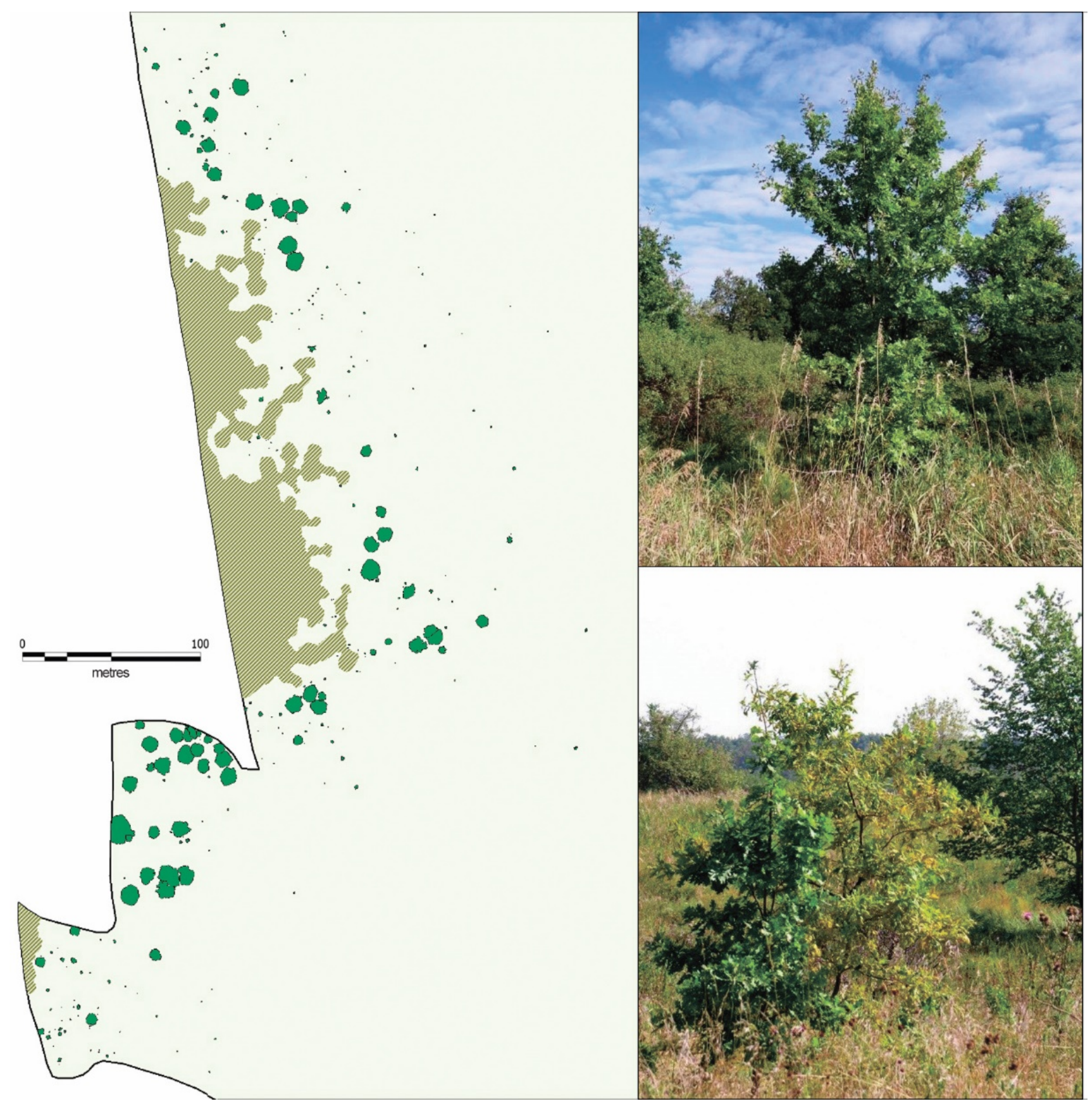

Figure 13. Natural seed regeneration of common oak in the ecotones between forest and virgin unmowed steppe (2016). Note. The image shows virginal oak plants on the Second unmowed section of Streletskaya steppe.

7. Abnormal weather conditions in 20092012, in particular heat and drought, led to the drying of upper soil horizons in the forests, which in turn caused a massive dying off of aspen trees, especially on Streletsky and Kazatsky sites of the CCR (Fig. 14). The woody vegetation of the "Osinovy Kust" forest PTP located on the Streletsky site in Petrin Les ecosite (Krasnitskij, 1983) was studied to the greatest extent. Aspen (Populus tremula L.) had been the dominant species of the stand here for a long time. The detailed cartographic studies that were performed at this site in 1975 and 2004, showed a significant increase in the projective cover of the aspen stand (Ryzhkova, Ryzhkov, 2006). However, the abovementioned weather anomalies drew aspen population to the stage of regression. In this case, mostly mature generative trees that made up the population nucleus of this species died (Fig. 15). The information about dying off of aspen stands and its dynamics has been published by (Ryzhkova et al., 2012; Ryzhkov D. et al., 2015; Ryzhkova et al., 2018). 

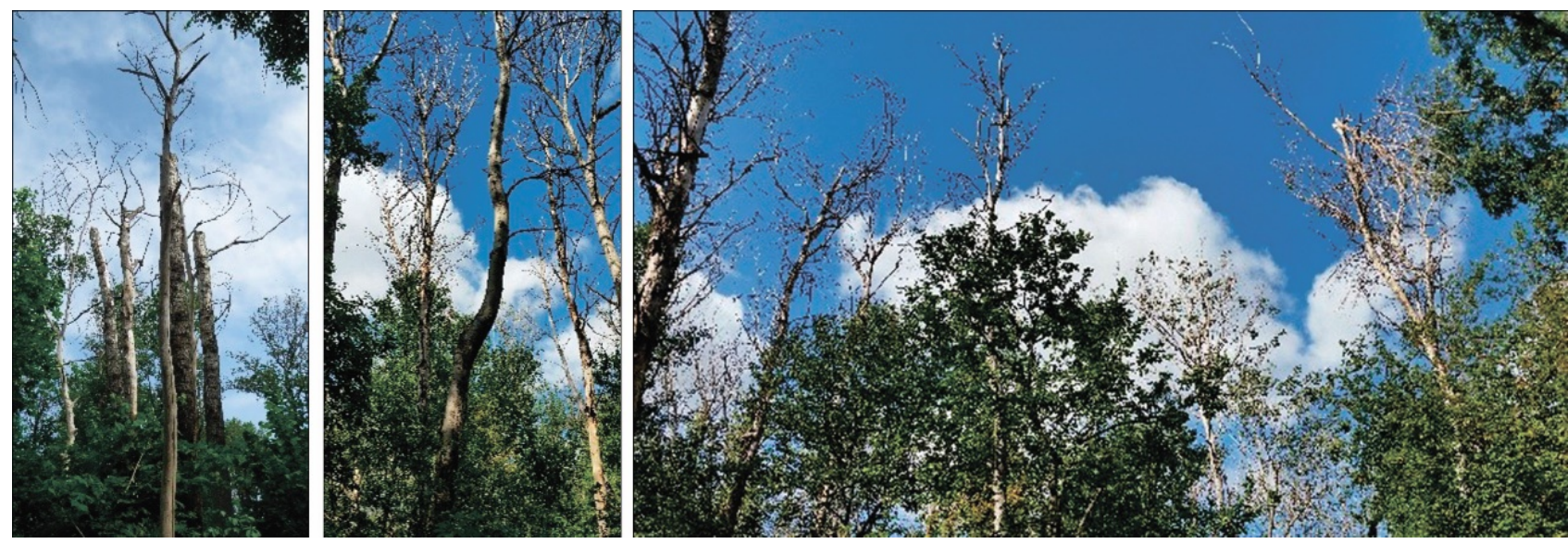

Figure 14. Disintegration of aspen stands on Kazatsky and Streletsky sites of the CCR

The process of disintegration of aspen stands is clearly demonstrated by the bar chart of long-term dynamics of the relative participation of aspen in the total woody litter, which decreased from $95.1 \%$ in 1970 to $2.4 \%$ in 2017 (Fig. 16).

8. In contrast to aspen, silver birch (Betula pendula Roth) has demonstrated an expansion of its growing area as evidenced by modern cartographic studies. This species was previously extremely rare in the CCR. Only 10 specimens under $4 \mathrm{~m}$ high were found in all the oak forests of Streletsky site, 6 trees in Solovyatnik, 1 tree in Petrin Les, and 3 trees in Dubroshina. (Alehin, 1940). New information appeared later about the distribution of birch: 99 trees in Solovyatnik, 7 trees in Dubroshina (Levickij, 1957).

In 1994, we performed complete enumeration and eye mapping of the location of birch trees in Dubroshina, Solovyatnik and Dedov-Vesely ecosites and published the resulting data on changes of the range of this species and its occurrence in the forests of Streletsky site of CCR (Ryzhkov, 1997). Sections of the northern slope of Petrin Log with the sparse tree tier and the presence of clearings turned out to be the most optimal ecotopes for birch settlement (Ryzhkov, 2001b). In 2008-2011 total ground GISmapping of silver birch population was made based on GIS-survey within Streletsky site, and accurate maps of silver birch distribution were created (Fig. 17). There were 1,514 trees of this species mapped in total, and the majority of them were highly viable (Ryzhkov, Ryzhkova, 2014c).

Thus, despite suboptimal light conditions of the modern forest communities of the reserve, Streletsky site still has the ecotopes that are suitable for the settlement and spread of silver birch, which is confirmed by the results of our research.

To improve visualization of birch settlement process, the method of draping the DTM with various raster images was applied (Ryzhkov, 2013).

During the field GPS-survey, collecting of attribute information was accompanied by taking pictures of each birch tree with subsequent linking of the images to the corresponding record in the geodatabase in GIS environment (Fig. 18). 

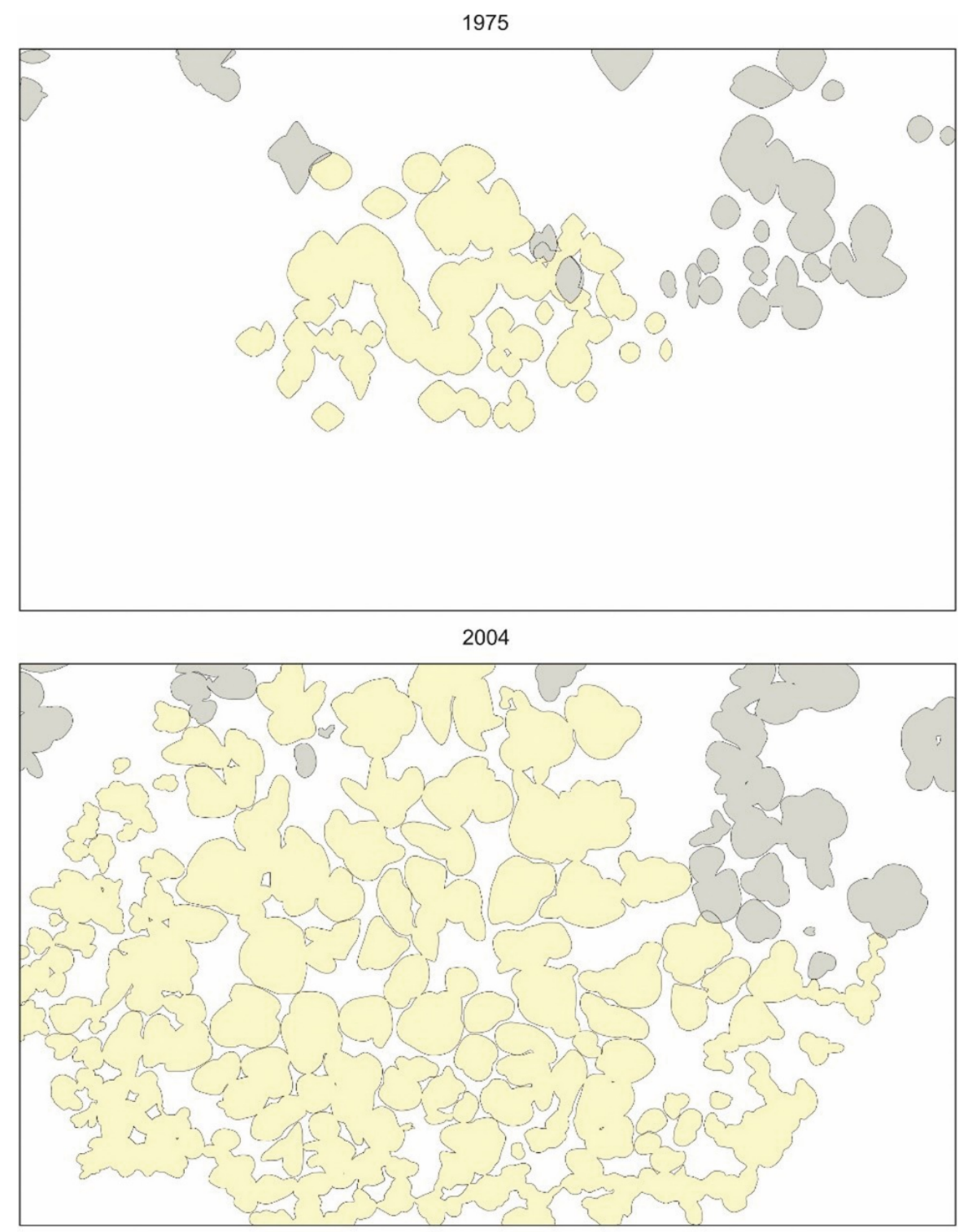

2017

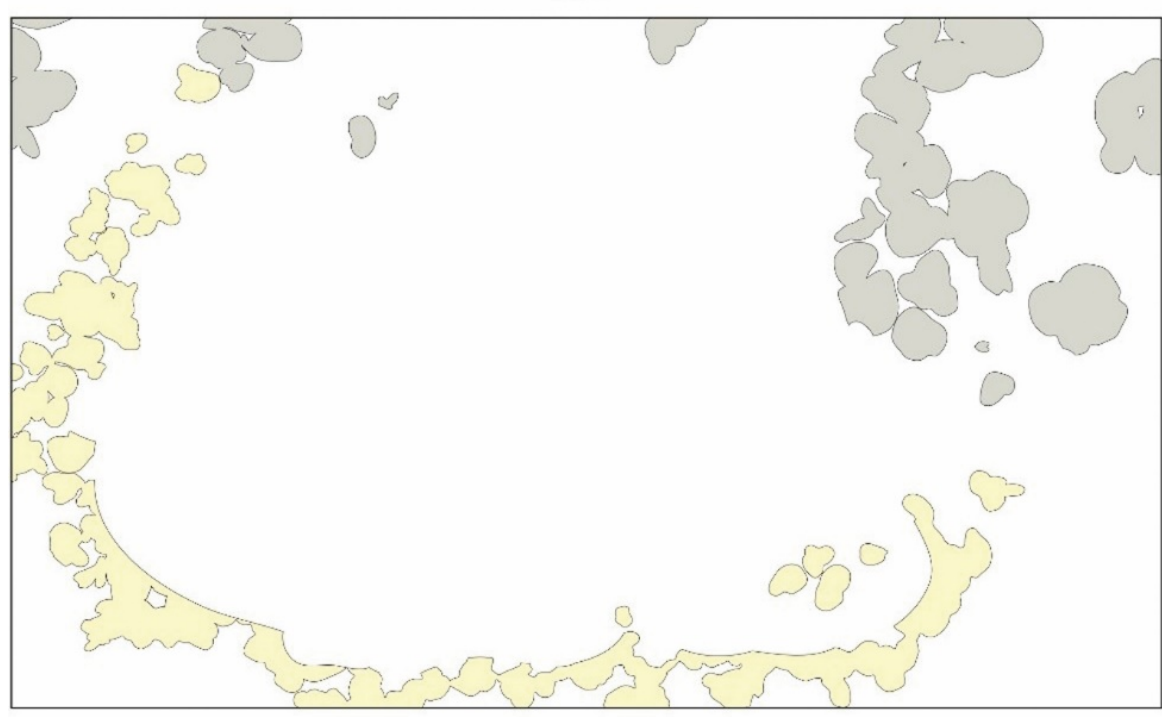

$\square$ - Quercus robur

- Populus tremula

Figure 15. Dynamics of aspen projective covers based on mapping materials of different years (Streletsky site, "Osinovy Kust" PTP). Note: in 2017, projections of aspen crowns were rendered visually without detailed field mapping. 


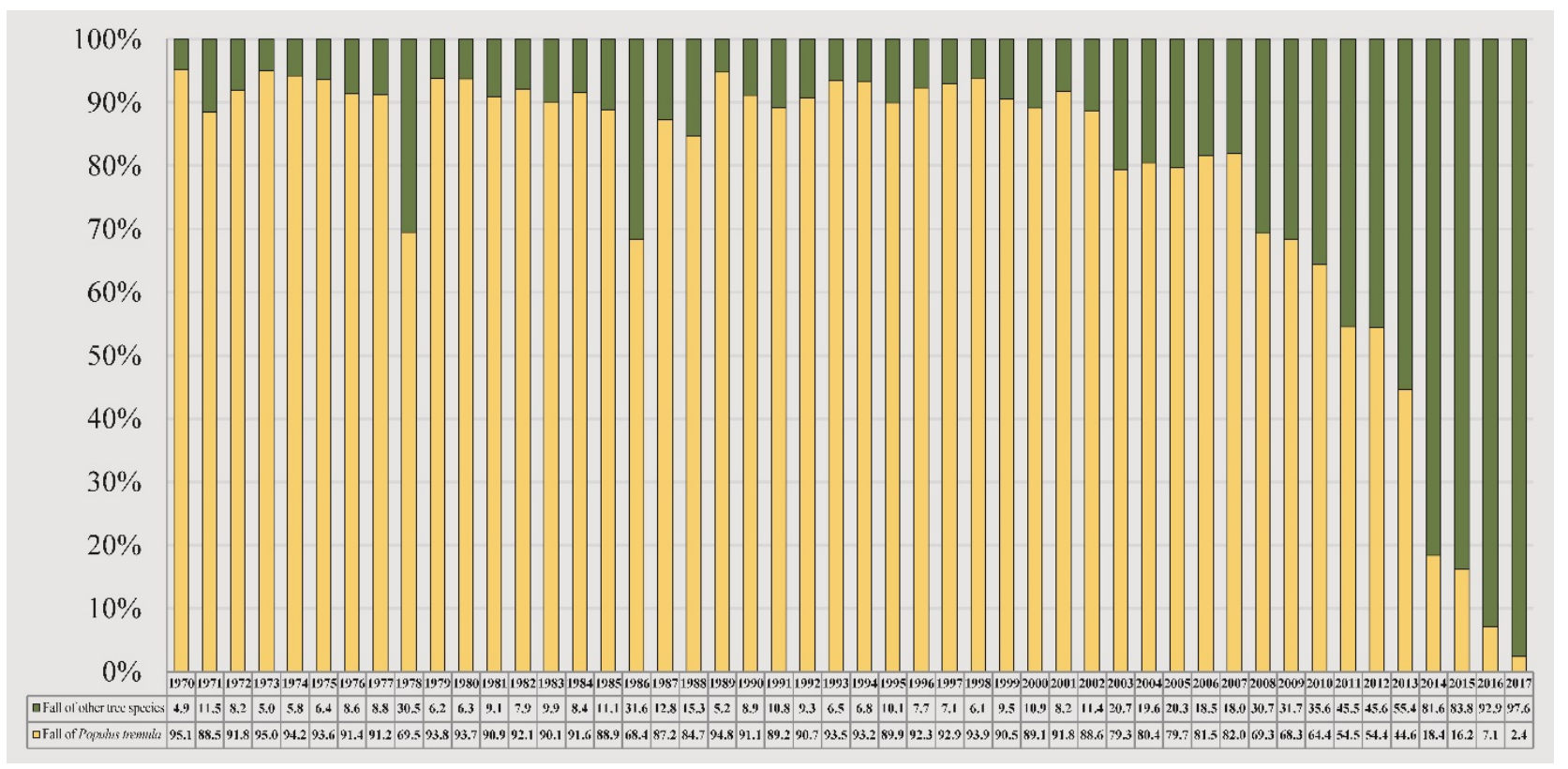

Figure 16. Dynamics of the relative participation of aspen fractions in the woody litter at "Osinovy Kust" forest PTP

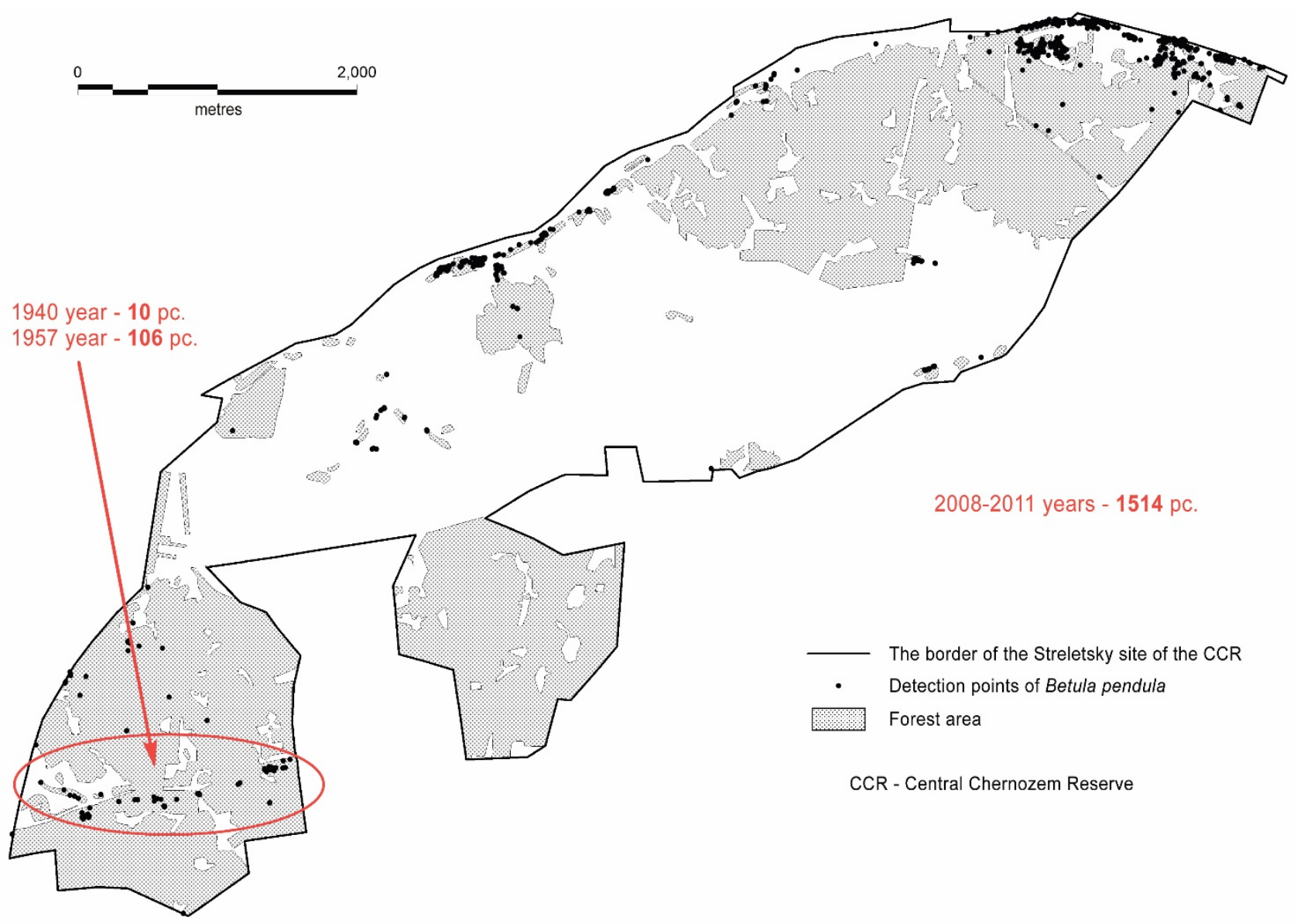

Figure 17. Scheme of distribution of the silver birch across Streletsky site of the Central Chernozem Reserve based on mapping data of 2008-2011 


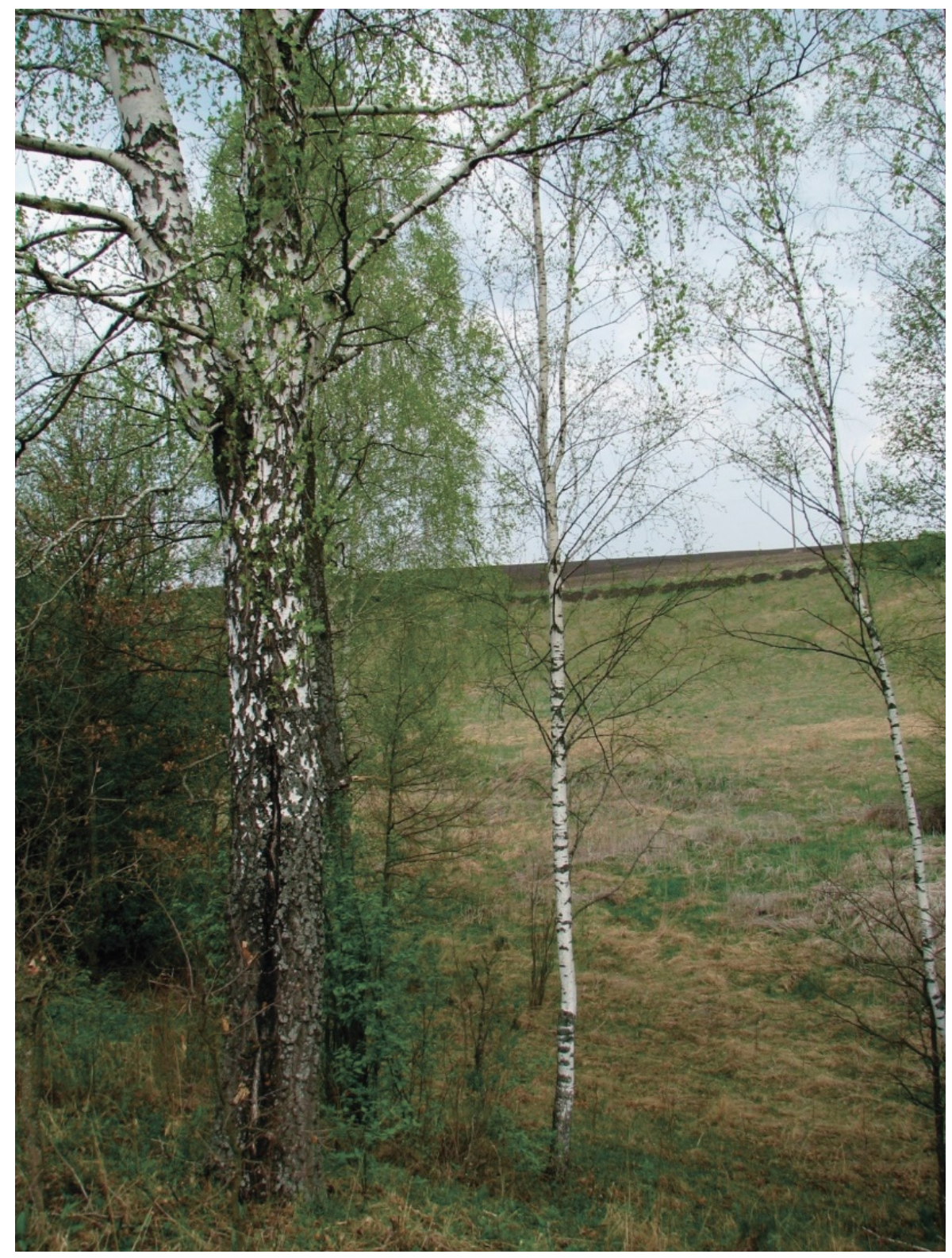

Figure 18. Visualization of an image of a silver birch tree from a GIS attribute table entry

9. Geoinformation mapping methods were also used to study populations of rare tree species inhabiting the reserve, in particular of the dwarf almond (Amygdalus nana L.). We have collected the most complete geospatial information concerning dwarf almond not only in the reserve but in Kursk oblast as a whole. The population of this species was mapped in detail in Khvoshchevoy Log of the Streletsky site of CCR in 2009, at Gorodnoye ecosite, Barkalovka site, and at Pokosnevo and Bukreevo ecosites, Bukreevy Barmy site in 2011, and at Kazatsky site in 2012-2013 where Barybin Log was found to have region's largest habitat of the species (Ryzhkov, Ryzhkova, 2012b). The method of total planimetric survey using satellite positioning devices was applied.

According to the mapping materials of 2012-2013, the total projective cover of dwarf almond on Kazatsky site of the CCR was 12.9 ha (Fig. 19). A DTM of the site territory was constructed. It served as the basis for generating polynomial covers of the main morphometric parameters of the terrain and enabled analyzing the spatial structure of the dwarf almond population depending on these parameters (Ryzhkov, Ryzhkova, 2014a,b). 


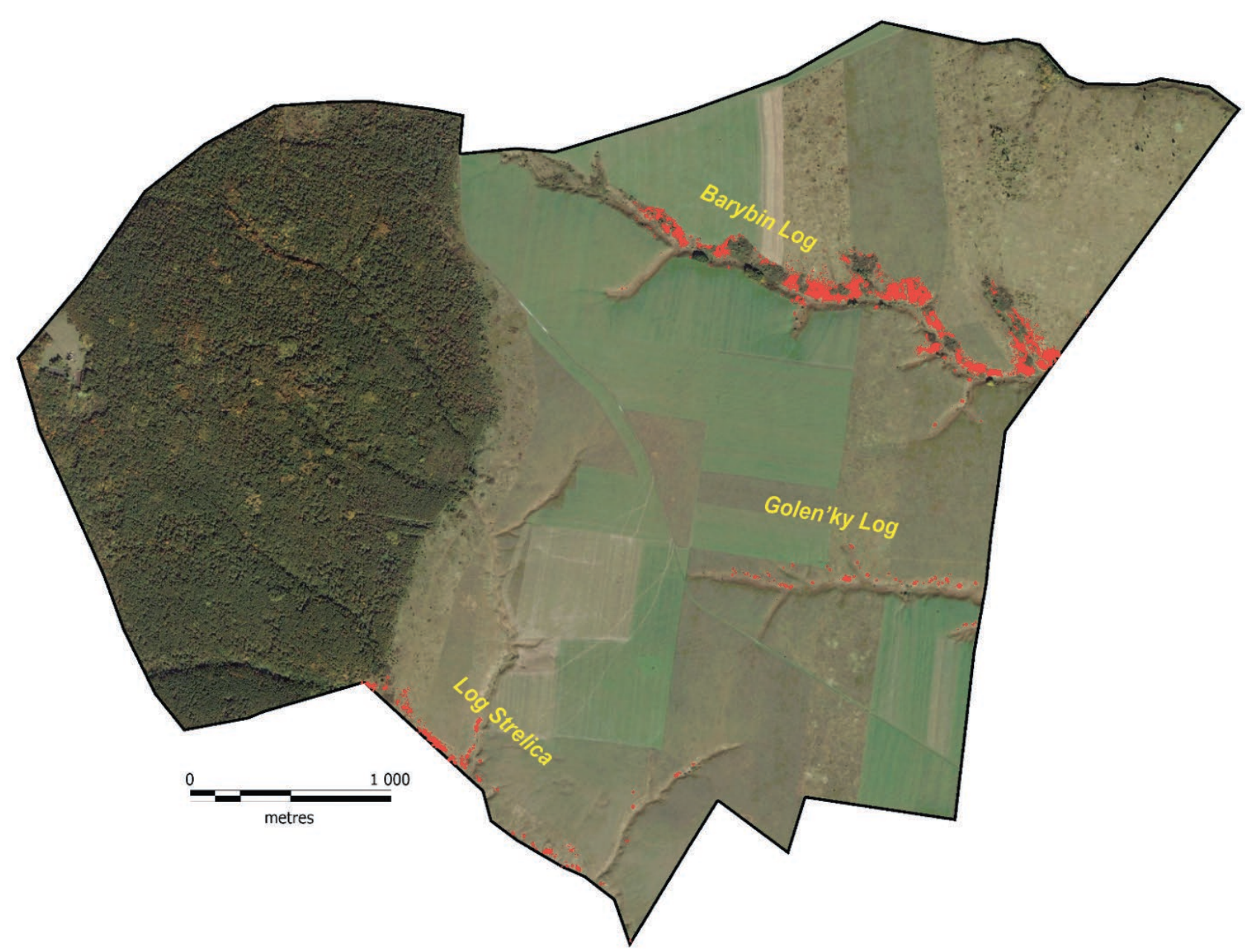

Figure 19. Scheme of projective covers of dwarf almond on Kazatsky site of the CCR, 2013

10. As noted, the Central Chernozem Reserve is located in the border area between forest and steppe, therefore the forest-steppe relationship has always been of great priority. Studying the distribution of tree and shrub vegetation both in former fallows and virgin steppes has its advantages over the study of typical forest ecosystems in terms of GIS, since in open spaces it is possible to use both personal navigators and high-precision GNSS equipment. The following were the most significant thematic cartographic works performed in the CCR using satellite positioning devices:

2007. Mapping of the distribution of woody vegetation on the fallows of Bukreevy Barmy site of the CCR.

The site is located in the central part of the Central Russian Upland, in the upper reaches of the Oskol river basin. The research was carried out on the largest fallow with an area of 20 ha. At the time of mapping, it was 29 years old. We recorded the coordinates of the plant trunk bases with a personal navigator Garmin GPSMap 78s. 38 species of trees and shrubs were identified in 2007. The data was processed with GIS analytical tools. Having a significant array of GPS points that have threedimensional coordinates and are more or less evenly distributed over the territory of the fallow, we were able to build maps of projective covers of tree and shrub species in the MapInfo environment. Vertical Mapper module was used for this purpose to generate heights-based raster network files or GRD files. The network of heights of specimens of woody species of Bukreevy Barmy site of the CCR, helped to create vector maps of projective covers of trees and shrubs with certain heights and calculate their areas. We believe that the possibility to obtain vector projective covers of tree and shrub vegetation from a GRD file is extremely important. This method can be considered as an alternative to 
time-consuming manual planimetric plotting of crowns on paper in the field (Ryzhkov, 2013).

2004, 2011. Mapping of the distribution of tree and shrub species in the pasture of Streletsky site of the CCR.

Dynamic maps of single-growing trees and shrubs were made in the above years on the test plots of 15.5 (2004) and 5.0 (2011) ha on the basis of GPS-surveys. Personal satellite navigators Garmin GPS 12CX (2004) and Garmin GPSMap 78s (2011) were used for mapping. MapInfo Professional 10.5.2 rus GIS helped to analyze the appearance and death of different types of trees and shrubs on the pasture test plot ( $5 \mathrm{ha}$ ) for the period from 2004 to 2011. It was found that the rate of repopulation of the groups of trees on pasture is about 18 trees per year per 5 ha, whereas the rate of elimination is about 5 trees per year (Ryzhkov, Ryzhkova, 2012a).

2016. Mapping of the distribution of woody vegetation on the Second unmowed section of Streletskaya steppe.

The satellite receiver of geodesic class Trimble GeoExplorer $6000 \mathrm{GeoXH} \mathrm{CE}$ and the DJI Inspire-1 UAV were used for the survey.

56 growing species of woody plants, including 23 species of trees and 33 species of shrubs were found in the area under survey (Ryzhkov et al., 2017). A total of 7,251 individual plants and 1,787 thickets were taken into account. The total projective cover of tree and shrub vegetation made up 14.3 ha (or $14.1 \%$ of the area of the Second unmowed section), of which single plants accounted for 3.0 ha and thickets - for 11.3 ha (Ryzhkov O. et al., 2017a,b). This value of the total projective cover is the highest among all previously mapped unmowed sections of the reserve. $1.6 \%$ of this value accounts for the forest, which in 80 years after the foundation of the unmowed section (from 1935 to 2016) has occupied 1.67 ha of it (Ryzhkov, Ryzhkova, 2018).

The Central Chernozem Reserve is actively developing cooperation, including international cooperation (Ryzhkov, Tregubov, 2006), in terms of mastering and sharing experience in the use of GPS and GIS technologies in protected areas (Solncev et al., 2006). Appropriate guidelines and practical training courses have been developed for the employees of nature reserves and national parks (Ryzhkov, 2007; Ryzhkov, 2009a).

\section{CONCLUSION}

Modern GIS technologies, especially those based on data collection using high-precision satellite positioning devices, quickly provide reliable information about natural objects and enable regular monitoring of their condition. Such monitoring provides the most valuable information by total mapping of woody vegetation of the CCR on permanent test plots, as well as by studying populations of individual species on protected areas. The accumulated long-term series of observations in conjunction with cartographic materials formed the basis for short-term forecasts of the development of forest ecosystems in the CCR (Ryzhkov, 2002). The main conclusions from the completed studies for the period from 1989 to 2019 are as follows:

1. Zonal forest forming species, i.e. the common oak, is gradually losing its role of the dominating species. Coppice oak stands of the 5th-6th generation cannot form viable undergrowth under the forest canopy and will be replaced unidirectionally by associate species. However, in ecotone zones between forest and steppe, where light is not a limiting factor of the environment, full-fledged populations of common oak develop with a significant proportion of plants of pregenerative stage. Thus, instead of coppice mother stands, in the long term seed oak forests, that will be geographically linked to the current forest edge, may develop.

2. Aspen stands of the CCR proved to be extremely sensitive to climatic anomalies and are currently at the disintegration stage. In some areas, the population is rejuvenated: rootshoots appeared after the death of generative trees, but it remains to be seen whether they will last for long. In most cases, former aspen forests are replaced with other types of forest with new wood edificators represented by shade-resistant species (most likely Norway maple).

3. Birch stands turned out to be more resistant to adverse environmental factors. Active spread of the silver birch is seen on the Streletsky site of the CCR, mainly along the 
slopes of the northern direction.

4. Powerful undergrowth of cherry and hazel has formed in oak forests, which also creates additional shade under the forest canopy. These species have almost completely displaced light-demanding shrubs (blackthorn, common buckthorn, rose hips, etc.) from oak forests. The area of hazel growth has a tendency to increase and spread from logs to watersheds; new centres of its settlement are found.

5. In the forest-steppe confrontation, the former is stronger now. In the natural course of processes, the CCR is experiencing afforestation of open areas (steppes, restored

\section{REFERENCES}

Alekhin V.V., Ocherk rastitel'nosti i ee posledovatel'noj smeny na uchastke Streleckaja step' pod Kurskom (Essay of vegetation and its successive change in the area of the Streletskaya steppe near Kursk), Tr. SPb. obshh. estestvoispytatelej, otd. botan., 1909, Vol. 40, Issue 1, 112 p.

Kartometricheskie issledovanija na territorii Central'no-Chernozemnogo zapovednika im. prof. V.V. Alekhina (Cartometric studies on the territory of the Central Chernozem reserve), Otchet IGAN SSSR za 1961-1975 gg. (sost. P.K. Rubajlo), Inv. No 438, 1975, 43 p.

Kashkarova V.P., Rubajlo P.K., Utehin V.D., Karta rastitel'nosti dal'nego nekosimogo uchastka Streleckoj stepi (Vegetation Map of the distant non-irrigated area of the Sagittarius steppe) Otchjot Central'noChernozemnogo gosudarstvennogo zapovednika im. prof. V.V. Alehina, 1973, Inv. No 425.

Krasnitskij A.M., Estestvennoe rasprostranenie derev'ev i kustarnikov na nekosimoj zalezhi v Central'noChernozemnom zapovednike (Natural distribution of trees and shrubs on an unattainable Deposit in the Central black earth reserve), Botan. zhurn., 1973, Vol. 58, No 2, pp. 212-224.

Krasnitskij A.M., Lesoobrazujushhaja rol' osiny $\mathrm{V}$ processah rasprostranenija $\mathrm{i}$ vozobnovlenija dubrav na primere osinovogo kusta v Central'noChernozemnom zapovednike (Forest- on former fallows; virgin meadow steppes in non-mowed mode; pastures, etc.).

The scope of potential application of geospatial information in forest science will undoubtedly be growing, as modern GIS technologies have already become an integral tool for understanding the nature of the forest.

\section{ACKNOWLEDGEMENTS}

In 2016, cartographic studies were carried out with the financial support of the project of $\mathrm{UNDP} / \mathrm{GEF} / \mathrm{Ministry}$ of natural resources of Russia No. $00072294 \quad$ "Improving the protected areas management system and mechanisms in the steppe biome of Russia".

Forming role of aspen in the processes of distribution and renewal of oak forests on the example of aspen Bush in the Central black earth reserve), Jekologocenoticheskie i geograficheskie osobennosti rastitel'nosti, Moscow, 1983, pp. 107-121.

Krasnitskij A.M., Soshnin G.P., Vnedrenie derev'ev i kustarnikov na nekosimyh uchastkah Central'no-Chernozemnogo zapovednika (The Introduction of trees and shrubs on nekomimi areas of the Central Chernozem reserve), Bjul. MOIP Otd. biol., 1984, Vol. 89, Issue 2, pp. 88-97.

Letopis' prirody Central'no-Chernozemnogo zapovednika (Chronicle of the nature of the Central black earth reserve), Book 2 (19411945), 1949, $34 \mathrm{p}$.

Letopis' prirody Central'no-Chernozemnogo zapovednika (Chronicle of the nature of the Central black earth reserve), Book 4 (19491950), 1951, 70 p.

Levickij S.S. Spisok sosudistyh rastenij Central'no-Chernozemnogo

gosudarstvennogo zapovednika (List of vascular plants of the Central Chernozem state reserve), In: Tr. Centr.-Chernozemn. gos. zapovednika (Tr. Center.-Chernozemn. state reserve), Kursk, 1957, Issue 4, pp. 110-173.

Nepochatyh L.V., Ryzhkov O.V., Klimat (Climate), In: Central'no-Chernozemnyj gosudarstvennyj prirodnyj biosfernyj zapovednik imeni professora V.V. Alehina (nauchno-populjarnoe izdanie), Pod obshh. red. A.A. Vlasova, O.V. Ryzhkova, N.I. Zolotuhina, Kursk: Mechta, 2016, pp. 1519. 
Neshataev Ju.N., Vyborochno-statisticheskij metod v detal'nom kartografirovanii dubrav (Sampling-statistical method in detailed mapping of oak forests), Krupnomasshtabnoe kartografirovanie rastitel'nosti, Novosibirsk: Nauka, 1970, pp. 56-65.

Neshataev Ju.N., Detal'noe krupnomasshtabnoe geobotanicheskoe kartirovanie kak objazatel'nyj jelement jekologicheskogo monitoringa (na primere biosfernogo Central'no-Chernozemnogo zapovednika) (Detailed large-scale geobotanical mapping as a mandatory element of environmental monitoring (on the example of the Central black earth biosphere reserve)), Regional'nyj jekologicheskij monitoring, Pushhino: NCBN SSSR, 1983, pp. 58-63.

Neshataev Ju.N., Nekotorye itogi izuchenija dinamiki rastitel'nosti Kazackogo uchastka Central'no-Chernozemnogo biosfernogo zapovednika metodom vyborochnostatisticheskogo kartografirovanija (Some results of studying vegetation dynamics of the Cossack site of the Central Chernozem biosphere reserve method of selectively and statistical mapping), In: Zapovednoe delo: Nauchno-metodicheskie zapiski komissii po zapovednomu delu, Issue 1. Moscow, 1996, pp. 35-40.

Neshataev Ju.N., Novikova L.A., Uhacheva V.N., Osnovnye tendencii izmenenija rastitel'nosti Kazackogo uchastka Central'no-Chernozemnogo zapovednika (po itogam geobotanicheskogo kartirovanija 1968 i 1979 gg.) (The main trends in the vegetation of the Cossack site of the Central black earth reserve (according to the results of geobotanical mapping in 1968 and 1979)), Nauchnoe nasledie V.V. Alehina $i$ razvitie ego idej $v$ zapovednom dele, Kursk, 1982, pp. 49-52.

Petrova I.F., Tendencii izmenenija lugovostepnoj rastitel'nosti Central'noj lesostepi (Tendencies of change of meadow-steppe vegetation of the Central forest-steppe), Moscow, 1990, $206 \mathrm{p}$.

Ryzhkov D.O., Ryzhkova G.A., Ryzhkov O.V., Raspad osinovyh nasazhdenij Central'no-Chernozemnogo zapovednika (The Decay of aspen plantations of the
Central black earth reserve), In: Biologicheskoe raznoobrazie kak osnova sushhestvovanija i funkcionirovanija estestvennyh i iskusstvennyh jekosistem: Mater. Vserosp. molodjozh. nauch. konf. (All-Russian. youth. scientific conf.) 8-10 June 2015, Voronezh: Istoki, 2015, pp. 267271.

Ryzhkov O.V., Sostojanie i razvitie dubrav Central'noj lesostepi (na primere zapovednikov Central'no-Chernozemnogo i "Les na Vorskle") (Condition and development of oak forests of the Central forest-steppe (on the example of reserves of the Central Chernozem and "Forest on Vorskla")), Avtoreferat dissertacii na soiskanie uchenoj stepeni kandidata biologicheskih nauk, Krasnodar, 1996a, 22 p.

Ryzhkov O.V., Stacionarnye issledovanija drevesnoj rastitel'nosti $\mathrm{V}$ zapovednikah (Stationary studies of woody vegetation in nature reserves), In: Pochvennyj $i$ bioticheskij monitoring zapovednyh jekosistem: Metodicheskoe posobie (Pochvennyj $i$ bioticheskij monitoring zapovednyh jekosistem: Metodicheskoe posobie), Moscow: KMK Scientific Press Ltd., 1996b, pp. 51-60.

Ryzhkov O.V., Dinamika sostava lesov Central'no-Chernozemnogo zapovednika (Forest composition Dynamics of the Central Chernozem reserve), In: Mnogoletnjaja dinamika prirodnyh processov i biologicheskoe raznoobrazie zapovednyh jekosistem Central'nogo Chernozem'ja i Altaja, Trudy Central'noChernozemnogo gosudarstvennogo zapovednika, Issue 15, M: KMK Scientific Press Ltd., 1997, pp. 73-86.

Ryzhkov O.V., Metodologija ispol'zovanija vektornyh kart rastitel'nosti v lesovedenii i vizualizacii graficheskoj informacii (Methodology of use of vector maps of vegetation in forest science and visualization of graphic information), In: Botanicheskie, pochvennye i landshaftnye issledovanija $\mathrm{v}$ zapovednikah Central'nogo Chernozem'ja: Tr. Associacii OOPT Central'nogo Chernozem'ja Rossii, Issue 1. Tula, 2000, p. 120-130. 
Ryzhkov O.V., Ispol'zovanie Autocad 2000 dlja sozdanija vektornyh kart lesnyh fitocenozov (Using Autocad 2000 to create vector maps of forest phytocenoses), In: Rastitel'nyj pokrov Central'noChernozemnogo zapovednika: $T r$. Centr.Chernozemn. gop. zapovednika, Issue 18, Tula, 2001a, pp. 82-93.

Ryzhkov O.V., Sostojanie i razvitie dubrav Central'noj lesostepi (na primere zapovednikov Central'no-Chernozemnogo $i$ "Les na Vorskle") (Condition and development of oak forests in the Central forest-steppe zone (by the example of nature reserves in the Central Chernozem and "Forest on the Vorskla")), Tula, 2001b, $182 \mathrm{p}$.

Ryzhkov O.V., Lesnye jekosistemy Central'no-Chernozemnogo zapovednika: proshloe, nastojashhee, budushhee (Forest ecosystems of the Central Chernozem reserve: past, present, future), In: Izuchenie i ohrana prirody lesostepi (Study and conservation of forest-steppe): ScientificPractical Conf., Dedicated. 120th Anniversary of the Birth of V.V. Alekhina), Tula, 17 January 2002, Tula, 2002, pp. 1114.

Ryzhkov O.V., Metodicheskie aspekty primenenija GPS i GIS dlja izuchenija osobo ohranjaemyh prirodnyh territorij (Methodological aspects of the use of GPS and GIS for the study of specially protected natural areas), In: Ispol'zovanie GPS- $i$ GIStehnologij dlja izuchenija osobo ohranjaemyh prirodnyh territorij (na primere landshaftnoj struktury Voronezhskogo gosudarstvennogo biosfernogo zapovednika) (The use of GPS - and GIS technologies for the study of specially protected natural areas (for example, the landscape structure of the Voronezh State Biosphere Reserve), Pod redakciej: V.N. Solnceva, O.V. Tregubova, O.V. Ryzhkova, B.A. Alekseeva, S. Kola, P. Uorda, Tula, 2006a, pp. 14-115.

Ryzhkov O.V., Obzor stacionarnyh kartograficheskih issledovanij rastitel'nosti Central'no-Chernozjomnogo zapovednika (Overview of the stationary mapping studies of the vegetation of the Central black earth reserve), In: Kartograficheskie issledovanija v Central'no-Chernozemnom zapovednike: Tr. Centr.-Chernozemn. gos. zapovednika, Issue 19, Kursk, 2006b, pp. 35-39.

Ryzhkov O.V., Ruchnoj i jelektronnyj metody opredelenija ploshhadej proektivnyh pokrytij drevostoev (obzor, preimushhestva i nedostatki, sravnenie) (Manual and electronic methods of determining the areas of projective cover of stands (review, advantages and disadvantages, comparison)), In: Kartograficheskie issledovanija v Central'no-Chernozemnom zapovednike: Tr. Centr.-Chernozemn. gop. zapovednika, Issue 19, Kursk, 2006c, pp. 138-140.

Ryzhkov O.V., Metodicheskoe posobie $k$ seminaru "Geoinformacionnye sistemy $i$ osobo ohranjaemye prirodnye territorii" (16-21 aprelja 2007, Elizovo) (Handbook for the seminar "Geoinformation systems and specially protected natural areas" (April 16-21, 2007, Elizovo), Tula: Grif i K, 2007 , $240 \mathrm{p}$.

Ryzhkov O.V., Primenenie metodov nazemnogo sputnikovogo pozicionirovanija i GIS dlja izuchenija redkih vidov bioty na osobo ohranjaemyh prirodnyh territorijah Kurskoj oblasti (Application of methods of terrestrial satellite positioning and GIS for the study of rare species of biota in specially protected natural areas of Kursk region), In: Principy i sposoby sohranenija bioraznoobrazija (Principles and Methods of Biodiversity Conservation III): AllRussian. scientific conf. Joshkar-Ola; Pushhino, 27 January - 1 February 2008, Joshkar-Ola; Pushhino, 2008, pp. 581-583.

Ryzhkov O.V., Kurs prakticheskih uprazhnenij k seminaru "Geoinformacionnye sistemy na osobo ohranjaemyh prirodnyh territorijah na primere nacional'nogo parka "Kurshskaja kosa" (9-15 nojabrja 2009 g., pop. Rybachij) (Course of practical exercises for the seminar "Geoinformation systems in specially protected natural areas on the example of the national Park "Kurshskaja kosa" (9-15 November 2009, Rybachy village)), Kaliningradskij regional'nyj fond sohranenija i razvitija nacional'nogo parka 
"Kurshskaja kosa", Proekt "Shkola sodruzhestva", Rybachij, 2009a, 195 p.

Ryzhkov O.V., Metody geoinformacionnogo kartografirovanija prirodnyh ob"ektov (Methods of geoinformation mapping of natural objects), In: Geoinformacionnoe kartografirovanie $\mathrm{v}$ regionah Rossii (Geoinformation Mapping in the Regions of Russia): mater All-Russiann scientificpractical conf.), Voronezh, 2-4 December 2009, Voronezh: Izd-vo "Istoki", 2009b, pp. 184-187.

Ryzhkov O.V., Ispol'zovanie novyh sredstv integracii GPS i GIS v srede Mapinfo professional 10.5 (modul' Geographic tracker 4.0) pri provedenii geograficheskih issledovanij (The Use of new means of integration of GPS and GIS in the environment Mapinfo professional 10.5 (module Geographic tracker 4.0) in the conduct of geographical research), In: Geoinformacionnoe kartografirovanie $v$ regionah Rossii (Geoinformation Mapping in the Regions of Russia): mater. II (correspondence) All-Russian scientificpractical. conf., Voronezh, 15 November 2010, Voronezhskij gosudarstvennyj universitet, Voronezh: Izd-vo "Nauchnaja kniga", 2010, pp. 63-68.

Ryzhkov O.V., Sovmestnoe ispol'zovanie GPS (GLONASS)-priborov i GIS pri kartografirovanii prirodnyh obektov $\mathrm{v}$ real'nom vremeni (Joint use of GPS (GLONASS)-devices and GIS in mapping natural objects in real time), In: Geoinformacionnoe kartografirovanie $v$ regionah Rossii (Geoinformation Mapping in the Regions of Russia): mater. III (correspondence) All-Russian scientificpractical. conf., Voronezh, 15-18 September 2011), Voronezhskij gosudarstvennyj universitet. Voronezh: Izd-vo "Nauchnaja kniga", 2011, pp. 111116.

Ryzhkov O.V., Razvitie geoinformacionnoj sistemy Central'no-Chernozemnogo zapovednika (Development of geoinformation system of the Central Chernozem reserve), In: InterKarto/InterGIS-19: Ustojchivoe razvitie territorij: teorija GIS $i$ prakticheskij opyt. (Intercarto / InterGIS-
19: Sustainable Development of Territories: GIS Theory and Practical Experience): Materials of the international conference, Kursk, Bogota (Kolumbija), 2-7 February 2013, Kursk, 2013, pp. 220-239.

Ryzhkov O.V., Metodika sozdanija sglazhennyh poligonov v srede MAPINFO PROFESSIONAL v.12.0 po dannym priborov sputnikovogo pozicionirovanija (Methodology of creation of anti-aliased polygons in the environment of MAPINFO PROFESSIONAL v.12.0 according to the satellite positioning devices), In: Sovremennye tehnologii $v$ dejatel'nosti OOPT (Modern Technologies in Activity of the OOPT): Mater international scientificpractical conf. (selected) 12-16 May 2014, Kurortnyj poselok Naroch', Belarus', 2014a, pp. 94-107.

Ryzhkov O.V., Priemy povyshenija tochnosti opredelenija koordinat i zapisi trekov personal'nymi GPS-navigatorami GARMIN pri s"emke prirodnyh ob"ektov (Methods of improving the accuracy of positioning and recording tracks personal GPS-navigators GARMIN when shooting natural objects), In: Sovremennye tehnologii $v$ dejatel'nosti OOPT (Modern Technologies in Activity of the OOPT): Mater international scientific-practical conf. (selected) 12-16 May 2014, Kurortnyj poselok Naroch', Belarus', 2014b, pp. 8693.

Ryzhkov O.V., Formirovanie sglazhennyh poligonov v srede Mapinfo Proffessional v.12.0 po dannym priborov sputnikovogo pozicionirovanija (Formation of smoothed polygons in Mapinfo Proffessional $\mathrm{V}$ environment.12.0 according to satellite positioning devices), In: Sovremennye tehnologii v dejatel'nosti OOPT (Modern Technologies in Activity of the OOPT): Mater international scientific-practical conf. (selected) 12-16 May 2014, Kurortnyj poselok Naroch', Belarus', 2014c, pp. 133134.

Ryzhkov O.V., Puzachenko A.Ju., Vlasov A.A., Zolotuhin N.I., Korol'kov A.K., Filatova T.D., Stoletnjaja dinamika klimata i bioty Central'noj lesostepi (na primere Central'no-Chernozemnogo zapovednika i prilegajushhih territorij (Centenary 
dynamics of climate and biota of the Central forest-steppe (on the example of the Central Chernozem reserve and adjacent territories), In: Vlijanie izmenenija klimata na jekosistemy: Serija publikacij Departamenta prirodoohrannoj politiki $i$ jekspertizy Vsemirnogo fonda dikoj prirody, Ohranjaemye prirodnye territorii Rossii. Analiz mnogoletnih nabljudenij, Issue 4, Moscow: Russkij universitet, 2001, pp. 6981.

Ryzhkov O.V., Ryzhkova G.A., Izuchenie gorizontal'noj struktury lesnyh soobshhestv na osnove vektornyh (cifrovyh) kart (Study of the horizontal structure of forest communities on the basis of vector (digital) maps), In: Rol' zapovednikov Kavkaza v sohranenii bioraznoobrazija prirodnyh jekosistem (The Role of the Caucasus Reserves in Preserving the Biodiversity of Natural Ecosystems) Yubil. conf., dedicated. 75th anniversary of the Caucasian GOP. natural biosphere. Reserve: Abstracts of reports, Sochi, 1999, pp. 60-63.

Ryzhkov O.V., Ryzhkova G.A., Analiz dinamiki rasprostranenija derev'ev i kustarnikov na zalezhi Kazackogo uchastka Central'no-Chernozemnogo zapovednika po materialam kartirovanija 1970, $1980 \mathrm{i}$ 1999 godov (Analysis of the dynamics of the spread of trees and shrubs on the deposits of the Cossack site of the Central Chernozem reserve on the materials of mapping 1970, 1980 and 1999), In: Botanicheskie, pochvennye i landshaftnye issledovanija v zapovednikah Central'nogo Chernozem'ja: Tr. Associacii OOPT Central'nogo Chernozem'ja Rossii, Issue 1, Tula, 2000a, p. 136-146.

Ryzhkov O.V., Ryzhkova G.A., Dinamika vnedrenija drevesno-kustarnikovyh vidov rastenij na nekosimoj zalezhi Kazackogo uchastka Central'no-Chernozemnogo zapovednika za 58 let (Dynamics of introduction of tree-shrub species of plants on the certain Deposit of the Cossack site of the Central Chernozem reserve for 58 years), In: Chtenija pamjati prof. V.V. Stanchinskogo (Readings Memory Prof. V.V. Stanchinsky), Issue 3, Smolensk: Izd- vo Smolenskogo gospeduniversiteta, 2000b, pp. 364-368.

Ryzhkov O.V., Ryzhkova G.A., Izmenenie chislennosti i proektivnogo pokrytija drevesno-kustarnikovyh vidov na nekosimoj zalezhi Kazackogo uchastka Central'no-Chernozemnogo zapovednika po materialam kartirovanija 1970, 1980 i 1999 godov (Changes in the number and projective cover of tree-shrub species on the certain deposits of the Cossack site of the Central Chernozem reserve based on the mapping materials of 1970, 1980 and 1999), In: Stepi severnoj Evrazii: strategija sohranenija prirodnogo raznoobrazija $i$ stepnogo prirodopol'zovanija $v$ XXI veke (The Steppes of Northern Eurasia: a Strategy for the Conservation of Natural Diversity and Steppe Environmental Management in the XXI Century): Mater. international symposium, Orenburg, 2000c., pp. 339-341.

Ryzhkov O.V., Ryzhkova G.A., Lesa Zorinskogo uchastka Central'noChernozemnogo zapovednika (Forests of the Zorinsky site of the Central Chernozem reserve), In: Prirodnye uslovija i biologicheskoe raznoobrazie Zorinskogo zapovednogo uchastka v Kurskoj oblasti: Tr. Centr.-Chernozemn. gop. zapovednika, Issue 17, Tula, 2001, pp. 140-186.

Ryzhkov O.V., Ryzhkova G.A., Vozrastnaja struktura i zhiznennoe sostojanie popolnenija drevostoev $\mathrm{V}$ dubravah Central'no-Chernozemnogo zapovednika (uchastki Barkalovka i Bukreevy Barmy) za period 1991-2003 gg. (Age structure and life as the replenishment of trees in the oak forests of the Central Chernozem reserve (areas Barkalova and Bukreeva the Barm) for the period 1991-2003 period), In: Aktual'nye problemy upravlenija zapovednikami v Evropejskoj chasti Rossii (Actual Problems of Management of Reserves in the European part of Russia): Materials anniversary scientific-practical. conf., dedicated 10th anniversary of the state. natural Reserve "Voroninsky", village Inzhavino, Tambov region, 21-24 September, 2004., Voronezh: Voronezhskij gosudarstvennyj universitet, 2004, pp. 138141. 
Ryzhkov O.V., Ryzhkova G.A., Analiz mnogoletnej dinamiki gorizontal'noj struktury dubrav Central'noChernozemnogo zapovednika na osnove stacionarnyh issledovanij (Analysis of long-term dynamics of the horizontal structure of oak forests of the Central Chernozem reserve on the basis of stationary studies), In: Kartograficheskie issledovanija v Central'no-Chernozemnom zapovednike: Tr. Centr.-Chernozemn. gop. zapovednika, Issue 19, Kursk, 2006a, pp. 52-64.

Ryzhkov O.V., Ryzhkova G.A., Ispol'zovanie navigacionnyh priborov dlja fiksacii mestonahozhdenij i predstavlenija kart arealov vidov iz Krasnoj knigi Kurskoj oblasti (The Use of navigation devices for fixing the locations and presentation of maps of species ranges from the red book of the Kursk region), In: Issledovanija po Krasnoj knige Kurskoj oblasti (Studies in the Red Book of the Kursk Region): Mat-ly scientific-practical. conf. Kursk region, Kursk district, village Zapovednyj, March 2006, Kursk, 2006b, pp. 9-12.

Ryzhkov O.V., Ryzhkova G.A., Izuchenie dinamiki rasprostranenija leshhiny obyknovennoj na Streleckom uchastke Central'no-Chernozemnogo zapovednika $\mathrm{s}$ ispol'zovaniem metodov GPS i GIS (Study of the dynamics of the distribution of common hazel on the Streletsky site of the Central black earth reserve using GPS and GIS methods), In: Geoinformacionnoe kartografirovanie $v$ geografii $i$ geojekologii: sbornik statej, Voronezhskij gosudarstvennyj universitet, Voronezh: Izd-vo "Istoki", 2010a, pp. 67-86.

Ryzhkov O.V., Ryzhkova G.A., Rasprostranenie Tilia cordata $\mathrm{v}$ lesnyh urochishhah Streleckogo uchastka CChZ (Distribution of Tilia cordata in the forest tracts of the Streletsky district of the Central black earth reserve), In: Problemy monitoringa prirodny processov na osobo ohranjaemyh prirodnyh territorijah (Problems of Monitoring Natural Processes in Specially Protected Natural Territories): mater international Scientific Practical konf., dedicate. 75th anniversary of the Khopzhor State nature reserve, village
Varvarino, Voronezh region, 20-23 September, 2010), Voronezh: VGPU, 2010b, pp. 377-379.

Ryzhkov O.V., Ryzhkova G.A., Ispol'zovanie GIS-kartografirovanija dlja izuchenija dinamiki rastitel'nogo pokrova pastbishha Central'no-Chernozemnogo zapovednika i proektirovanija zapovedno-rezhimnyh meroprijatij (Use of GIS mapping to study the dynamics of vegetation cover of the pasture of the Central Chernozem reserve and the design of conservation measures), In: Mater. mezhdunar. nauch.-prakt. konf., posvjashh. 130-letiju so dnja rozhdenija professora V.V. Alehina (Mater International Scientific-Practical Conf., Dedicated the 130th Anniversary of the Birth of Professor V.V. Alekhina), Kursk, village Zapovednyj, 15-18 January 2012), Kursk, 2012a, pp. 168-187.

Ryzhkov O.V., Ryzhkova G.A., GPSkartografirovanie populjacij mindalja nizkogo na uchastkah Central'noChernozemnogo zapovednika Barkalovka i Bukreevy Barmy v 2011 godu (GPS mapping populations of almonds low on the territories of Central-Chernozem reserve Barkalova and Bukreeva the Barm in 2011), In: Geoinformacionnoe kartografirovanie v regionah Rossii (Geoinformation Mapping in the Regions of Russia): mater IV (absentee) Vserop. scientific-practical conf., Voronezh, 15 November, 2012, Voronezh: Izd-vo "Nauchnaja kniga", 2012b, pp. 105-110.

Ryzhkov O.V., Ryzhkova G.A., Ispol'zovanie cifrovoj modeli rel'efa dlja izuchenija prostranstvennoj struktury populjacii mindalja nizkogo v Central'noChernozemnom zapovednike (The Use of digital elevation model to study the spatial structure of the low almond population in the Central black earth reserve), In: Aktual'nye problemy jekologii Rossii i stran blizhnego zarubezh'ja (Actual Problems of Ecology of Russia and Neighboring Countries): mater All-Russian scientific conf. from Intern. participation (Kursk, 12 November, 2013), Kursk, 2014a, pp. 80-83.

Ryzhkov O.V., Ryzhkova G.A., Ispol'zovanie cifrovyh modelej rel'efa dlja analiza geoprostranstvennyh dannyh Central'no- 
Chernozemnogo zapovednika (The Use of digital elevation models for the analysis of geospatial data of the Central Chernozem reserve), In: Sovremennye tehnologii $v$ dejatel'nosti OOPT (Modern Technologies in the Activities of Protected Areas), Mater international scientific-practical conf. (selected), 12-16 May 2014, The resort village Naroch, Belarus', 2014b, pp. 108144.

Ryzhkov O.V., Ryzhkova G.A., Primenenie metodov GIS-kartografirovanija dlja izuchenija dinamiki rasprostranenija berezy povisloj (Betula pendula Roth) na Streleckom uchastke Central'noChernozemnogo zapovednika v 2008-2011 godah (Application of GIS mapping methods to study the dynamics of the spread of birch (Betula pendula Roth) on the Streletsky site of the Central Chernozem reserve in 2008-2011), In: Flora $i$ rastitel'nost' Central'nogo Chernozem'ja 2014 (Flora and Vegetation of the Central Black Earth Region - 2014): Mater interregion. scientific conf. (Kursk, 5 April, 2014), Kursk, 2014c. pp. 148-153.

Ryzhkov O.V., Ryzhkova G.A., Les i step' v Central'no-Chernozemnom zapovednike: metody i rezul'taty kartografirovanija rastitel'nosti (1999-2016 gg.) (Forest and steppe in the Central Chernozem reserve: methods and results of vegetation mapping (1999-2016)), In: Sbornik tezisov Vserossijskoj nauchnoj konferencii "Nacional'naja kartograficheskaja konferencija - 2018" (Book of abstracts of the All-Russian Scientific Conference "National Cartographic Conference 2018"), M., Rossijskaja gosudarstvennaja biblioteka, 16-19 October 2018, M.: Geograficheskij fakul'tet MGU, 2018, pp. 237-238, DOI: $10.15356 /$ ncc2018; http://ncconf.ru/.

Ryzhkov O.V., Ryzhkova G.A., Dinamika sostojanija drevostoev pojmennyh dubrav uchastka Pojma Psla Central'noChernozemnogo zapovednika (Dynamics of forest stands of floodplain oak forests of the floodplain area of the Central Chernozem reserve), In: Flora $i$ rastitel'nost' central'nogo Chernozem'ja 2019 (Flora and Vegetation of the Central
Chernozem Region - 2019): Mater. Interregion. scientific konf., dedicate. 50year-old organization of participants in the Central Chernozem Reserve Barkalovka and Bukreeviy Barma, Zapovedny village, 13 April, 2019, Kursk: Mechta, 2019a, pp. 140-146.

Ryzhkov O.V., Ryzhkova G.A., Rezul'taty izuchenija lesnyh jekosistem Central'noChernozemnogo zapovednika na osnove GIS-tehnologij (Results of the study of forest ecosystems of the Central Chernozem reserve on the basis of GIS technologies), In: Ajerokosmicheskie metody $i$ geoinformacionnye tehnologii $v$ lesovedenii, lesnom hozjajstve $i$ jekologii (Aerospace methods and geo-information technologies in forest science, forestry and ecology), Moscow, 22-24 April, 2019, Moscow: CFEP RAN, 2019b, pp. 157-159.

Ryzhkov O.V., Ryzhkova G.A., Nepochatyh L.V., Mnogoletnjaja dinamika otpada stvolov duba chereshchatogo $\mathrm{v}$ lesah Central'no-Chernozemnogo zapovednika (Long-term dynamics of mortality of the trunks of oak-trees in the forests of the Central Chernozem reserve), In: Flora $i$ rastitel'nost' Central'nogo Chernozem'ja 2013 (Flora and Vegetation of the Central Chernozem Region - 2013): Mater interregion. scientific conf., Kursk, 6 April, 2013, Kursk, 2013, pp. 132-138.

Ryzhkov O.V., Ryzhkova G.A., Ryzhkov D.O., Obzor novyh vozmozhnostej versii 11.5 GIS MapInfo Professional dlja sozdanija kart proektivnyh pokrytij rastitel'nosti na osnove splajnov (Review of new features of version 11.5 of GIS MapInfo Professional for creating maps of projective vegetation coatings based on splines), In: Flora $i$ rastitel'nost' Central'nogo Chernozem'ja - 2013 (Flora and Vegetation of the Central Chernozem Region - 2013): Mater interregion. scientific conf., Kursk, 6 April, 2013, Kursk, 2013, pp. 138-140.

Ryzhkov O.V., Ryzhkova G.A., Ryzhkov D.O., Metodika GIS-kartografirovanija drevesnoj rastitel'nosti $\mathrm{s}$ ispol'zovaniem sovremennyh apparatnyh i programmnyh sredstv (Methods of GIS mapping of woody vegetation using modern hardware and 
software), In: Sovremennye tehnologii $v$ dejatel'nosti osobo ohranjaemyh prirodnyh territorij: geoinformacionnye sistemy, distancionnoe zondirovanie zemli: sbornik nauchnyh statej - Minsk, 2017a, pp. 63-72.

Ryzhkov O.V., Ryzhkova G.A., Ryzhkov D.O., Proektivnye pokrytija drevesnokustarnikovoj rastitel'nosti Vtorogo nekosimogo uchastka Streleckoj stepi Central'no-Chernozemnogo zapovednika po materialam kartografirovanija 2016 goda (Projective covers of tree-shrub vegetation of the Second non-existent section of the Streletskaya steppe of the Central Chernozem reserve based on the mapping materials of 2016), Vestnik $T v G U$, Serija "Biologija i jekologija", 2017b, No 3, pp. 91-99.

Ryzhkov O.V., Ryzhkova G.A., Ryzhkov D.O., Rezul'taty kartirovanija populjacii duba chereshchatogo na Vtorom nekosimom uchastke Streleckoj stepi Central'no-Chernozemnogo zapovednika v 2016 godu (Results of mapping the population of English oak on the Second non-irrigated area of the Streletskaya steppe of the Central Chernozem reserve in 2016), In: Flora $i$ rastitel'nost' Central'nogo Chernozem'ja - 2017 (Flora and Vegetation of the Central Black Earth Region - 2017): mater interregion. scientific conf., Kursk, 8 April 2017, Kursk: Mechta, 2017c, pp. 126131.

Ryzhkov O.V., Ryzhkova G.A., Zolotuhin N.I., Zolotuhina I.B., Filatova T.D., Mnogoletnie rjady dannyh Central'noChernozemnogo zapovednika i vozmozhnosti ih migracii v GIS (LongTerm data series of the Central Chernozem reserve and the possibility of their migration to GIS), In: Sovremennye tehnologii $v$ dejatel'nosti osobo ohranjaemyh prirodnyh territorij: geoinformacionnye sistemy, distancionnoe zondirovanie Zemli: sbornik nauchnyh statej, Minsk, 2018, pp. 64-69.

Ryzhkov O.V., Sobakinskih V.D., Obzor geobotanicheskogo i lesnogo kartografirovanija uchastkov i urochishh Central'no-Chernozjomnogo zapovednika (Review of geobotanical and forest mapping of sites and tracts of the Central
Chernozem reserve), In: Kartograficheskie issledovanija v Central'no-Chernozemnom zapovednike: Tr. Centr.-Chernozemn. gop. zapovednika, Issue 19, Kursk, 2006, pp. 634.

Ryzhkov O.V., Tregubov O.V., Razvitie rossijsko-amerikanskogo sotrudnichestva po ispol'zovaniju GPS- i GIS- tehnologij na osobo ohranjaemyh prirodnyh territorijah (Development of Russian-American cooperation on the use of GPS and GIS technologies in specially protected natural areas), In: Ispol'zovanie GPS - $i$ GIStehnologij dlja izuchenija osobo ohranjaemyh prirodnyh territorij (na primere landshaftnoj struktury Voronezhskogo gosudarstvennogo biosfernogo zapovednika) (The use of GPS - and GIS technologies for the study of specially protected natural areas (on the main landscape structure of the Voronezh State Biosphere Reserve), Pod redakciej: V.N. Solnceva, O.V. Tregubova, O.V. Ryzhkova, B.A. Alekseeva, S. Kola, P. Uorda, Tula, 2006, pp. 197-208.

Ryzhkov O.V., Vlasov A.A., Metod sozdanija vektornyh kart lesnyh fitocenozov dlja ispol'zovanija v sistemah GIS (Method of creating vector maps of forest phytocenoses for use in GIS systems), In: GIS v nauchnyh issledovanijah zapovednikov Sibiri (GIS in the Research of Reserves in Siberia): Tez. report conf., dedicated. 75 th anniversary of the gop. natural Reserve "Stolby", Krasnojarsk, 2000, pp. 14-15.

Ryzhkov O.V., Vlasov A.A., Ryzhkova G.A., Filatova T.D., Zolotuhin N.I., Zolotuhina I.B., Nepochatyh L.V., Vlasova O.P., Vlasov E.A., Mnogoletnjaja dinamika klimata i bioty Streleckogo uchastka Central'no-Chernozjomnogo zapovednika (Long-Term dynamics of climate and biota of the Streletsky site of the Central Chernozem reserve), In: Voprosy geografii, Sb. 143, Geograficheskie osnovy zapovednogo dela (k 100-letiju zapovednoj sistemy Rossii), Redkol.: V.M. Kotljakov, A.A. Chibiljov, A.A. Tishkov, Moscow: Izd. dom "Kodeks", 2017a, pp. 267-285.

Ryzhkov O.V., Vlasov A.A., Ryzhkova G.A., Filatova T.D., Zolotuhin N.I., Zolotuhina I.B., Nepochatyh L.V., Vlasova O.P., 
Vlasov E.A., Monitoring klimata i bioty Streleckogo uchastka Central'noChernozemnogo zapovednika (The monitoring of the climate and biota of the Streletsky site of the Central Chernozem nature reserve), In: Tr. Mordovskogo gop. prirod. zapovednika im. P.G. Smidovicha, E.V. Vargot (otv. red.), A.B. Ruchin, A.A. Hapugin, Saransk - Pushta, 2017b, Issue 18, pp. 17-32.

Ryzhkov O.V., Zolotuhin N.I., Ryzhkova G.A., Vidovoj sostav dendroflory Vtorogo nekosimogo uchastka Streleckoj stepi Central'no-Chernozemnogo zapovednika (po materialam kartirovanija 2016 goda) (Species composition of the dendroflora of the Second non-irrigated area of the Streletskaya steppe of the Central Chernozem reserve (based on the mapping of 2016)), In: Vseros. nauch. konf. "Nauchnye issledovanija na zapovednyh territorijah" (All-Russia. Scientific Conf. "Scientific Research in Protected Areas"): book of abstracts, Simferopol': IT "ARIAL", 2017, pp. 43.

Ryzhkova G.A., Ryzhkov O.V., Nekotorye rezul'taty issledovanija gorizontal'noj struktury zapovednyh dubrav (Some results of the study of the horizontal structure of protected oak forests), In: Materialy Rossijsko-Ukrainskoj nauchnoj konferencii, posvjashhjonnoj 60-letiju Central'no-Chernozemnogo zapovednika (Materials of the Russian-Ukrainian scientific conference dedicated to the 60th anniversary of the Central Black Earth Reserve), Moscow: KMK Scientific Press Ltd., 1995, pp. 125-127.

Ryzhkova G.A., Ryzhkov O.V., Rasprostranenie drevesno-kustarnikovyh vidov na nekosimyh zalezhah Kazackogo uchastka Central'no-Chernozemnogo zapovednika (Distribution of tree-shrub species on certain deposits of the Cossack site of the Central Chernozem reserve), In: Rastitel'nyj pokrov Central'noChernozemnogo zapovednika: Tr. Centr.Chernozemn. gos. zapovednika, Tula: Grif i $\mathrm{K}^{\circ}, 2001$ (na oblozhke 2002), Issue 18, pp. 94-224.

Ryzhkova G.A., Ryzhkov O.V., Rasprostranenie cheremuhi obyknovennoj v lesnyh jekosistemah Central'noChernozemnogo zapovednika na osnove analiza mnogoletnih nabljudenij za opadom (Distribution of common bird cherry in forest ecosystems of the Central Chernozem reserve based on the analysis of long-term observations of the fall), In: Flora $i$ rastitel'nost' Central'nogo Chernozem'ja 2003 (Flora and Vegetation of the Central Black Soil Region - 2003): mat-ly science. conf., Kursk, 2003, pp. 28-31.

Ryzhkova G.A., Ryzhkov O.V., Dinamika listovogo opada $\mathrm{V}$ dubravah Central'noChernozemnogo zapovednika (Dynamics of leaf litter in the oak forests of the Central Chernozem reserve), Lesovedenie, No 5, 2004, pp. 20-27.

Ryzhkova G.A., Ryzhkov O.V., Dinamika rastitel'nosti lesnoj postojannoj probnoj ploshhadi "Osinovyj kust" po materialam kartirovanij raznyh let (Dynamics of vegetation of the forest permanent trial area "Aspen Bush" on the materials of mapping of different years), In: Kartograficheskie issledovanija v Central'no-Chernozemnom zapovednike: Tr. Centr.-Chernozemn. gop. zapovednika, Issue 19, Kursk. 2006, pp. 103-110.

Ryzhkova G.A., Ryzhkov O.V., Izuchenie dinamiki rasprostranenija leshhiny obyknovennoj na Streleckom uchastke Central'no-Chernozemnogo zapovednika s ispol'zovaniem metodov GPS i GIS (dopolnenie) (Study of the dynamics of the distribution of common hazel on the Streletsky site of the Central black earth reserve using GPS and GIS methods (Supplement), In: Geoinformacionnoe kartografirovanie $v$ regionah Rossii (Geoinformation Mapping in the Regions of Russia) mater. III All-Russian scientificpractical conf., Voronezh, 15-18 September 2011, Voronezhskij gosudarstvennyj universitet. Voronezh: Izd-vo "Nauchnaja kniga", 2011. pp. 117-120.

Ryzhkova G.A., Ryzhkov O.V., Nepochatyh L.V., Usyhanie osinovyh nasazhdenij Central'no-Chernozemnogo zapovednika (Desiccation of aspen plantations of the Central Chernozem reserve), In: Flora $i$ rastitel'nost' Central'nogo Chernozem'ja 2012 (Flora and Vegetation of the Central 
Chernozem Region - 2012): Mater. nauch. konf., Kursk, 6 April 2012, Kursk: Kurskij gos. un-t, 2012, pp. 138-142.

Ryzhkova G.A., Ryzhkov O.V., Ryzhkov D.O., Raspad osinovyh nasazhdenij Central'no-Chernozemnogo zapovednika (2008-2017 gody) (Decay of aspen plantations in the Central Chernozem reserve (2008-2017), In: Flora $i$ rastitel'nost' Central'nogo Chernozem'ja 2018 (Flora and Vegetation of the Central Chernozem Region - 2018): Mater. nauch. konf., Kursk, 21 April 2018, Kursk: Mechta, 2018, pp. 105-111.

Solncev V.N., Ryzhkov O.V., Tregubov O.V., Alekseev B.A., Kaluckova N.N., Anciferova A.A., Ispol'zovanie GPS- $i$ GIStehnologij dlja izuchenija osobo ohranjaemyh prirodnyh territorij (na primere landshaftnoj struktury Voronezhskogo gosudarstvennogo prirodnogo biosfernogo zapovednika) (The use of GPS and GIS technologies for the study of specially protected natural areas (on the example of the landscape structure of the Voronezh state natural biosphere reserve)). Tula: Grif i K, 2006, 216 p.
Utehin V.D., Rastitel'nost' Central'noChernozemnogo zapovednika i ee produktivnost' (Vegetation of the Central Chernozem reserve and its productivity), Biogeografija, fenologija, 1967, Issue 1, pp. 18-21.

Zolotuhin N.I., Ryzhkov O.V., Filatova T.D., Istorija organizacii, nauchnye issledovanija i obshhie svedenija o Zorinskom uchastke Central'noChernozemnogo zapovednika (the History of the organization, scientific research and General information about the Zorinsky area of the Central black earth reserve), In: Prirodnye uslovija i biologicheskoe raznoobrazie Zorinskogo zapovednogo uchastka v Kurskoj oblasti: Tr. Centr.Chernozemn. gos. zapovednika, Issue 17, Tula, 2001, pp. 7-30.

Zozulin G.M., Kusmarceva N.M., Izmenenie granic drevesno-kustarnikovoj i travjanistoj rastitel'nosti na opytnyh uchastkah Central'no-Chernozemnogo zapovednika za 5 let (Changing the boundaries of tree-shrub and herbaceous vegetation in the experimental areas of the Central Chernozem reserve for 5 years), Botan. zhurn., 1951, Vol. 36, No 3, pp. 240-248.

Reviewer: PhD in technology, researcher Podolskaya E.S. 